\title{
PUŁKOWNIK REDL. POLITYCZNE WĄTKI AFERY W PRASIE POLSKIEJ
}

\author{
KRZYSZTOF STĘPNIK
}

\begin{abstract}
Krzysztof Stępnik, Pułkownik Redl. Polityczne watki afery w prasie polskiej (Colonel Redl. Political motifs of the affair in Polish press releases).
\end{abstract}

Balcanica Posnaniensia. Acta et studia, XIX, Poznań 2012, Wydawnictwo Instytutu Historii UAM, pp. 249-286, ISBN 978-83-63-047-17-7, ISSN 0239-4278. Polish text with a summary in English.

Krzysztof Stępnik, Uniwersytet Marii Curie-Skłodowskiej, Wydział Politologii, Zakład Komunikacji Społecznej, Plac Litewski 3, 20-080 Lublin.

Najgłośniejsza afera szpiegowska w ostatnich latach przed wybuchem I wojny światowej miała miejsce w okresie nasilonych dyplomatycznych zabiegów wokół zakończenia wojny na Bałkanach, uwieńczonych postanowieniami pokojowymi konferencji ambasadorów w Londynie w końcu maja 1913 roku. Kilka dni wcześniej, w nocy z 24 na 25 maja (z soboty na niedzielę) zdemaskowany wskutek akcji kontrwywiadowczej pułkownik Alfred Redl, szef sztabu stacjonującego w Pradze VIII korpusu popełnia samobójstwo w wiedeńskim hotelu Klomser, do czego bezpośrednio popchnęła go powołana $\mathrm{w}$ trybie nadzwyczajnym komisja składająca się $\mathrm{z}$ oficerów wysokiej rangi. O sprawie wiedziała zaprzysiężona wąska grupa ludzi, a mimo to niemal natychmiast przedostała się ona do prasy wskutek niezwykłego wyczucia wagi spostrzeżenia pewnego ślusarza i inteligentnego rozegrania pozyskanej informacji przez asa reportażu Egona Erwina Kischa, dziennikarza ukazującej się w języku niemieckim praskiej „Bohemii”’ . W pewnym zakresie porównać by do niego można dwóch dociekliwych dziennikarzy „Washington Post”: Boba Woodwarda i Carla Bernsteina , którzy kilkadziesiąt lat później odsłonili kulisy afery Watergate.

Tylko dzień, dwa dni po samobójstwie gazety w peryferyjnych notkach odnotowują ten fakt, tłumacząc go - za oficjalnym komunikatem - napadem obłędu pułkow-

\footnotetext{
${ }^{1}$ Por. E. Erwin Kisch, Jarmark sensacji, tłum. z jęz. niemieckiego Stanisław Wygodzki, Warszawa 1957 (rozdz. Jak dowiedziałem się, że Redl byt szpiegiem) oraz tegoż Praski Pitaval, tłum. z jęz. niemieckiego Edyta Sicińska, Warszawa 1957 (rozdz. Upadek szefa sztabu generalnego Redla), Warszawa 1957.
} 
nika lub też jego przepracowaniem mającym związek ze sztabowymi pracami, nasilonymi wskutek wojny na Bałkanach. Jednakże wkrótce wybucha bomba, i w prasie ukazującej się na terenie Austro-Węgier wylewa się na Europę i świat sensacyjna wiadomość, że szef sztabu VIII korpusu w Pradze i szef biura ewidencyjnego, a więc kontrwywiadu zwalczającego szpiegów, sam okazuje się superszpiegiem, pracującym na rzecz ościennego mocarstwa, czyli Rosji. Aferę określa się mianem „niebywałej” i „niesłychanej”, a dzienniki środkowo-europejskie czynią zeń przez dwa tygodnie przedmiot ześrodkowanego zainteresowania swoich czytelników. Przejawem tego jest wyodrębnianie przez poszczególne redakcje specjalnych bloków tematycznych poświęconych tej aferze, w których informacje biur (agencji) korespondencyjnych przeplatają się z różnego rodzaju sensacyjnymi przypuszczeniami podawanymi zwłaszcza za licznymi tytułami prasy wiedeńskiej i czeskiej. Mnóstwo jest przedruków, które powodują standaryzację informacji, ale poszczególne dzienniki odpowiednio je figurują politycznie i opatrują komentarzem.

Afera pułkownika Redla staje się sensacją dziennikarską, dla której, gdyby szukać niedawnej analogii, jeśli chodzi o jej reperkusję, to znaleźć by ją można w wydarzeniach 1912 roku: katastrofie „Titanica” i rozbiciu komanda anarchistyczno-bandyckiego we Francji. Te wydarzenia miały swój symboliczny wyraz w postaci wytworzenia przez prasę światową globalnych szwarccharakterów: Bruce'a Ismaya, dyrektora „White Star Line”, który miał ponaglać kapitana „Titanica' do bicia rekordu prędkości, wskutek czego doszło do katastrofy, i Julesa Bonnota, przywódcy komanda terroryzującego Paryż i jego okolice. Naturalnie, w poczcie takich superszwarccharakterów można by umieścić pułkownika Redla, a ograniczając się do gruntu polskiego, na pewno czołowe miejsce zajęliby: hr. Bogdan Ronikier i Damazy Macoch, czy baron Jan Bisping, których zbrodnie i rozprawy sądowe im wytoczone bez reszty absorbowały w tym czasie polską opinię publiczną we wszystkich zaborach. Również, jeśli chodzi o szpiegostwo wojskowe, najzupełniej nagminne w tamtych mało dyskretnych czasach, pułkownik Redl otwierałby listę ,asów”, i można by rozważać jego działalność na tle wzmożonych działań agenturalnych w okresie, kiedy rosło na nie zapotrzebowanie, bo w dobie zbrojnego pokoju i wojny na Bałkanach, grożącej ryzykiem przekształcenia się w wojnę mocarstw europejskich. Można powiedzieć, że afera pułkownika Redla doskonale mieściła się w paradygmacie sensacji, za którą wskutek spotęgowanej konkurencji czyhały wręcz goniące za poczytnością tytuły prasowe. Rywalizacja była ostra, więc nie mogło być mowy o przeoczeniu takiego absolutnego newsa.

Autora niniejszego szkicu interesować będzie jednak nie tyle sensacja, ile jej polityczne wyzyskanie, także w celu skompromitowania określonej antagonistycznej formacji. Afera Redla pojawiła się bowiem w samym środku walki politycznej toczonej przez dwie wzajemnie i zaciekle zwalczające się orientacje: austriacką i rosyjską. Przypadła na okres coraz wyraźniej rysującego się podziału wśród Polaków, których szczyt przypadł po wybuchu wojny w 1914 roku. Znalazła się w polu rozbratu, jaki zaznaczył się pomiędzy endecją a niepodległościowcami, pomiędzy Komitetem Obywatelskim a Komisją Tymczasową Skonfederowanych Stronnictw 
Niepodległościowych, pomiędzy stawianiem na Rosją lub na Austro-Węgry, na status quo albo na hazard wojny, pomiędzy Królestwem a Galicją w myśleniu o ewentualnym przyszłym polskim Piemoncie. Podział generalny nie był jednak podziałem absolutnym, gdyż pozycja endecji w Galicji była wcale mocna i stanowiła niebłahą opcjonalną możliwość dla wyborców w stosunku do konserwatystów, socjalistów, ludowców i demokratów. Inna sprawa, że stanowiła ona cześć systemu politycznego Austro-Węgier, i to ją różniło od endecji warszawskiej- w myśl poglądów jej przeciwników - jawnie stojącej na gruncie panslawizmu, moskalofilstwa i ugody. Pod uwagę weźmiemy tytuły prasy głównie krakowskiej, lwowskiej i warszawskiej, mając na względzie to, iż w ten sposób zarysuje się główny dzielnicowy i orientacyjny obraz reakcji politycznej na interesującą nas aferę (oczywiście, podział dzielnicowy niekoniecznie pokrywał się z podziałem na orientację rosyjską i austriacką). Sprawy te wypadnie jednak poprzedzić uwagami na temat sytuacji politycznej c. k. Monarchii w kontekście wojny na Bałkanach i rzutowanie jej na sprawy polskie, na zjawiska, które ta wojna sprowokowała i ich konsekwencje, niekiedy natury aferalnej.

Wojna, o której mowa, nie była dla Polaków pod względem sposobu informowania o niej rubryką spraw odległych, którą można było poddać spokojnej lekturze w jakiejś kawiarni lwowskiej czy krakowskiej. Austro-Wegry były bowiem jedynym mocarstwem europejskim mocno osadzonym na Bałkanach, także militarnie, i również nie bez obecności Polaków. W roku 1913 tylko w Bośni i Hercegowinie służyło kilka tysięcy Galicjan, nie mówiąc o początkach wojny, czyli dobie częściowej mobilizacji c. k. armii (Rosja też podjęła podobne kroki). Z wymarszem „na Serbię” zetknęły się rzesze przerzucanych koleją żołnierzy polskich. Ale ważniejszy pod względem psychologicznym był stan „pogotowia wojennego", utrzymywany przez niedawno utworzony ruch strzelecki, manifestujący swoją obecność musztrami i „ćwiczeniami polowymi”, wskutek tego stwarzający sugestię kadr wojska polskiego. Nazwa: Polski Skarb Wojskowy dobrze informowała o charakterze gromadzonego funduszu, choć jego efekt finansowy był nader nieokazały. Z kolei nazwa Komisji Tymczasowej Skonfederowanych Stronnictw Niepodległościowych mogła kojarzyć się przynajmniej z surogatem rządu, ale w istocie nie znaczyła więcej niż reprezentacja polityczna partii wojny, z luźnym do niej akcesem poszczególnych stronnictw.

Ponadto niepokoje polityczne w Galicji podsyca publiczna debata nad reforma prawa wyborczego. Temperatura dyskusji i polemik jest wysoka, o czym świadczą mityngi partyjne, a ich ważnym punktem kulminacyjnym jest wystąpienie biskupów katolickich z listem pasterskim do wiernych, odczytanym w kościołach w niedzielę 25 maja 1913 roku. List adresowany był do środowisk politycznych odpowiedzialnych za losy kraju, przestrzegał przed łatwowiernym uleganiem agitatorom urabiającym nastawienia wsi polskiej, deklarował uznanie dla demokratyzacji systemu kurialnego i zaznaczał wagę pozytywnych stosunków polsko-ukraińskich (podobnie jak nieco późniejszy list pasterski grecko-katolickiego episkopatu ruskiego). Ale troska o zachowanie parytetów narodowościowych miała na tyle swój ciężar gatunkowy, że faktycznie zwracała się przeciwko założeniom reformy prawa wyborczego. To niezwykłe wystapienie polityczne pięciu hierarchów Kościoła katolickiego roz- 
pętało prawdziwą burzę, prowokując redakcje dzienników i tygodników w Galicji i Królestwie do zaznaczenia do niego swojego stosunku. List znalazł się niejako w oku cyklonu politycznego, który spotęgował zawirowania, ale skutku realnego nie wywołał, podobnie jak inne manifestacje i akcje stronnictw, gdyż do reformy nie doszło. Niemniej jest to dobry przykład odnoszący się do turbulencji, jakim podlegały wówczas sejmy krajowe c. k. Monarchii. Demokratyzacja życia i zmiana stosunków społecznych wytwarzały nacisk na istniejące prawo wyborcze, ale ten nacisk nie przybierał jakiejś ustalonej formy, gdyż szereg innych czynników, zwłaszcza narodowościowych, nie pozwalał na dalej idące zmiany. W sprawozdaniach z sejmów krajowych i z Izby Poselskiej w Wiedniu wyraz „obstrukcja”, kwitujący stan debaty parlamentarnej lub jej wyniki, bije rekordy frekwencji.

Niepokoje polityczne związane są też z klęską gospodarczą Galicji, jako skutkiem wojen bałkańskich. Głośno komentowane jest w prasie wystapienie prezesa Koła polskiego w Wiedniu w dniu 28 maja, w którym roztoczona została czarna wizja stanu przemysłu i stosunków finansowych w Galicji². Doktor Juliusz Leo mówił w nim o „najgwałtowniejszym przesileniu kredytowym”, „druzgocącej sile depresji gospodarczej” oraz o „osłabieniu wszelkiej inicjatywy gospodarczej i przedsiębiorczości”. Stan klęski gospodarczej pogłębiają według niego „błędy systemu administracyjnego", zaś o wielkiej nędzy najlepiej świadczy zwiększająca się fala emigracji. Nie funkcjonują należycie świadczenia dla rodzin rezerwistów powołanych do służby wojskowej. Oczywiście, są to ekonomiczno-gospodarcze i społecznej skutki wojny na Bałkanach, które nie ominęły Galicji. Ten pogląd zostaje bezpośrednio wyartykułowany:

Naród polski obok ludów bałkańskich najbardziej bezpośrednio dotknęły ostatnie wypadki wojenne. Grożący zatarg z Rosją wywołał straszne przesilenie w Galicji, która bez rzeczywistej wojny zmuszona była płacić bardzo bolesne koszty wojenne ${ }^{3}$.

Prezes dotknął też sprawy ofiarności młodzieży polskiej, która wraz z narodem gotowa była walczyć w obronie c. k. Monarchii, wytykając jednak temu państwu prowadzenie niewłaściwej polityki wobec Słowian południowych. Pomimo użycia niezwykle intensywnych słów malujących czarny obraz życia gospodarczego Galicji, konkluzja wystąpienia jest państwowotwórcza:

Upatrujemy w Austrii państwo, powołane przez Opatrzność do wypełnienia historycznej szczytnej misji równouprawnienia licznych swych ludów4

Te formułę uznać można za kwintesencję konserwatywnego punktu widzenia, naturalnie, kontestowaną przez przeciwników lojalizmu galicyjskiego.

\footnotetext{
2 Omówienie w urzędowej „Gazecie Lwowskiej” 1913, nr 120 (29 maja), s. 5 i nr 121 (30 maja), s. 1.

3 „Gazeta Lwowska” 1913, nr 121 (30 maja), s. 1.

${ }^{4}$ Tamże, s. 2.
} 
Galicja nie była samotną wyspą na państwowej mapie c. k. Monarchii, składającej się przecież z krajów autonomicznych z funkcjonującą w nich reprezentacją sejmową i rządową (urząd namiestnika). Właśnie ten wysoki urząd objął we Lwowie dr Witold Korytowski, a prasa galicyjska w ramach specjalnego serwisu informacyjnego w końcu maja 1913 roku przedstawia szczegóły audiencji ceremonialnych odbywanych u tego dygnitarza. Niemało spraw dzieje się, więc, w Galicji i w „polskim” Wiedniu w ostatnim tygodniu maja: list episkopatu, wystąpienie w Izbie posłów prezesa Leo, objęcie urzędu przez nowego namiestnika.

Nie inaczej jest w innych krajach c. k. Monarchii, na przykład działalność sejmu krajowego w Pradze paraliżowana jest, między innymi, wskutek antagonizmu czesko-niemieckiego. Nawet prasa endecka, z natury czechofilska, daje wyraz swojemu zaniepokojeniu z powodu rysów pojawiających się na wyidealizowanym obrazie Czecha. Namiestnik Thun osobiście zainteresowany jest postępami śledztwa prowadzonego w Pradze w sprawie Redla. Natomiast w Chorwacji trwa stan wojenny i zawieszona jest konstytucja.

Galicyjskie parametry napięcia i przesilenia znajduja przeto swoje odpowiedniki w pozostałych krajach dualistycznej Monarchii. Co więcej, te odpowiedniki są na tyle istotne, że poważnie nadwerężają stabilność państwa austro-węgierskiego. Przybierają też postać sensacji, która upowszechniana przez prasę, chcąc nie chcąc podważa powagę ustrojową monarchii Habsburgów i utrwala stereotypy o jej chronicznej niezdolności do reform wewnętrznych i śmielszych projektów prowadzenia polityki imperialnej. Afera Redla miała swoją wagę, ale jej natychmiastowe dopełnienie znajduje swój wyraz w równolegle się rozgrywającej, jak to określił „Ilustrowany Kurier Codzienny”, ,panamie węgierskiej”. Do Wiednia, w którym rozegrał się finał afery szpiegowskiej dołączył Budapeszt. Właśnie sąd węgierski w drugiej instancji uwolnił od winy posła opozycji Zoltána Desy'ego, który nazwał premiera László Lukácsa

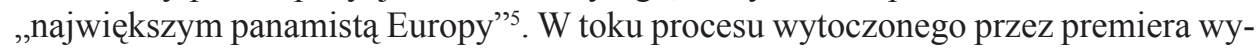
szło na jaw, że Bank węgierski przelał na konto partii rządzącej kwotę 4800000 koron. Udowodniono, więc, zaskoczonemu przebiegiem sprawy Lukácsowi, że dopuścił się on korupcji politycznej na taką skalę, że swoim rozmiarem przypomina ona aferę panamską. W efekcie zmuszony on został do podania się do dymisji. Opozycja parlamentarna zatryumfowała, a jej poseł Justh odczytał odezwę do narodu węgierskiego, która oczywiście sprowokowała do wyjścia na ulice przeciwników rządu. Sejm węgierski staje się widownią skandalicznych zachowań posłów, ale miarkę przebiera jednak osławiony w ówczesnej prasie kapitan straży sejmowej Gerö, który cięciem szabli rani posła Héderváry'ego i powala go na ziemię. Wybucha niesłychany w dziejach parlamentaryzmu skandal, a jeden z posłów wznosi znamienny okrzyk odnoszą-

\footnotetext{
${ }^{5}$ Znaczenie tego terminu wyjaśnia „Głos Narodu” 1913, nr 126 (5 czerwca), s. 2 w artykule Największy panamista w Europie: ,panamistami” nazwano po raz pierwszy tych ministrów i deputowanych francuskich, którzy przekupieni przez Towarzystwo budowy kanału panamskiego uchwalali emisję coraz to nowych akcji na budowę kanału, prowadzoną nieuczciwie, bez kontroli i bez fachowego kierownictwa".
} 
cy się do tej straży: „Gwardia Redla!”6. Na jedną aferę nakłada się więc druga, innego rodzaju, ale uderzająca mocno w podstawy moralne monarchii Franciszka Józefa. Sprzyjający porządkowi prawnemu Austro-Węgier, i nawet znajdujący zrozumienie dla postawy Lukácsa i potem Tiszy, krakowski „Czas” w artykule o znamiennym tytule Panama pisał ze zgrozą:

\begin{abstract}
Dziwne rzeczy dzieją się na Węgrzech, dziwne i brzydkie. Najwyżsi dygnitarze państwowi, ministrowie i sekretarze stanu, osobistości o historycznych nazwiskach, na oku całego narodu obwiniają się nawzajem o korupcję, a w obronie nawet zdradzają przerażający zanik publicznego sumienia i jakąś aż grozą przejmującą naiwność korupcji. Ma się wrażenie, że na Węgrzech zanikło poczucie różnicy pomiędzy Złem a Dobrem?
\end{abstract}

„Ilustrowany Kurier Codzienny” określił natomiast Lukácsa mianem „napiętnowanego szachraja politycznego i korupcjonisty”, dającego „zastraszające dowody dekadencji moralności publicznej”8. W myśl opinii redakcji „skandaliczna panama węgierska” wespół z aferą Redla ,wstrząsnęły niemal podwalinami Monarchii”. Skojarzenie to nieobce jest prasie warszawskiej, na przykład konkluzja pewnego komentarza politycznego w „Bluszczu”, w którym opis tych dwóch afer skwitowano słowem „To istotnie gorzej niż Panama!’9. Również tygodnik ilustrowany „Ziarno” w korupcji politycznej Lukácsa dostrzegł „podobny” jak afera Redla skandal, tym razem przydarzający się „,drugiej połowie monarchii”'10. Naturalnie, w epoce rozkwitu prasy ilustrowanej redakcje uciekały się do zdjęć i rysunków prasowych. W „Ilustrowanym Kurierze Codziennym” na stronach tytułowych pojawiają się rysunki przedstawiające pułkownika Redla i scenę zranienia posła Héderváry’ego w budapeszteńskim sejmie ${ }^{11}$, a w krakowskich „Nowościach Ilustrowanych” stronę tytułową numeru 23 otwiera rysunek przedstawiający scenę samobójstwa pułkownika w hotelu Klomsera ${ }^{12}$ w Wiedniu. Również prasa warszawska zamieszczała fotografie Redla $^{13}$ i rysunki obrazujące wypadki w sejmie budapesztańskim ${ }^{14}$.

${ }^{6} \mathrm{Na}$ samym początku wojny na froncie serbskim żołnierze armii austro-węgierskiej wypowiadają się lekceważąco o swoim dowództwie: „Sami Redle! Jeden w drugiego, przekupieni szubrawcy, sami szpiedzy, sami zdrajcy!’. Egon Erwin Kisch, Zapisz to Kisch!, tłum. z jęz. niemieckiego Anna Linke, Warszawa 1957, s. 68. Notka datowana jest: czwartek 20 sierpnia 1914.

7 „Czas” 1913, nr 254 (5 czerwca, wyd. popoł.), s. 1.

8 Artykuł redakcyjny Skandale w Austro-Wegrzech, „Ilustrowany Kurier Codzienny” 1913, nr 127 (5 czerwca), s. 2.

${ }^{9} \mathrm{~N}$ [atalia] J[jastrzębska] w rubryce Polityka daleka i bliska, „Bluszcz” 1913”, nr 24 (14 czerwca), s. 268 .

${ }^{10}$ Lech [pseudonim] w rubryce Kronika polityczna, „Ziarno” 1913, nr 23 (7 czerwca), s. 366.

$11 \mathrm{~W}$ numerach 127 (5 czerwca) i 127 (7 czerwca).

12 Będziemy używać formy typu: w hotelu Klomsera (jak w ówczesnej prasie), a nie: w hotelu ,Klomser”.

13 „Tygodnik Ilustrowany” 1913, nr 24, s. 468, „Świat” 1913, nr 24 (czerwca), s. 33 - w tymże numerze także fot. Władysława Lukácsa na s. 19 i rys. Walki w parlamencie węierskim na s. 12, „Złoty Róg” 1913, nr 24 (15 czerwca), s. 9.

14 Por. przypis 7 oraz rys. W parlamencie węgierskim, „Mucha” 1913, nr 14 (13 czerwca), s. 4. 
Wiedeń i Budapeszt stają się, więc, sezonowymi stolicami skandalu, symbolicznie obrazującymi sytuację, że ryba psuje się od głowy. Morale c. k. armii zostaje podważone, a opozycja sejmowa w stolicy Węgier wykazuje mocne natężenie tendencji odśrodkowych także wśród Madziarów. A przecież są jeszcze Czesi ze swoim antygermanizmem i panslawistycznym spoglądaniem w stronę Rosji. To nastawienie zostaje też aferalnie spersonalizowane przez posła czeskiego Václava Klofácza, orędownika neoslawizmu i zacieśniania związków z południową Słowiańszczyzną na niwie gospodarczej, ale nie bez pewnych zamiarów politycznych, sprzecznych z interesem państwowym c. k. Monarchii. Udającego się do Serbii posła zatrzymano na granicy w Zemuniu, ale po jego protestach umożliwiono mu kontynuowanie misji. Miała ona na celu pośredniczenie $\mathrm{w}$ dostawach produktów prężnego przemysłu czeskiego na rynek serbski, co Wiedniowi nie było miłe, ale jakoś dało się tolerować. Afera wybuchła, gdy okazało się, że list (intencyjny, jak byśmy dziś powiedzieli) dotyczący tego przedsięwzięcia zawierał sfałszowany podpis wybitnego polityka czeskiego Karela Kramárza. Sprawa oparła się o trybunał, i poseł Klofácz musiał gęsto thumaczyć się zapewne nie tylko z powodu tego fałszerstwa. W dobie afery Redla kontrwywiad z nadmiarem musiał wykazywać czujność. Tego należy się domyślać, choć sama sprawa nie przybrała jakiegoś szczególnie skandalicznego rozmiaru. Opisywał ja jednak uważnie krakowski miesięcznik „Świat Słowiański” w numerach z czerwca i lipca 1913 roku. Pismo to, reprezentujące austrosłowiański punkt widzenia na politykę c. k. Monarchii i zwalczające neoslawizm nie mogło nie zauważyć tej sprawy. Nie był to jakichś ideologiczny antyczechizm, lecz baczenie na to, by polityka ,jugosłowiańska" Austro-Węgier (określenie redaktora naczelnego Feliksa Konecznego) nie doznała szwanku ze strony żywego w Czechach panslawizmu.

Wreszcie, jeszcze jedno iunctim w tym przedziwnym kwartecie sensacji z przełomu maja i czerwca 1913 roku. Oto w ostatnich dniach urzędowania osławiony premier Lukács przyjął dymisję równie osławionego komisarza królewskiego i bana Chorwacji, Slavko Cuvaja. Choć Chorwat, miał on wśród swoich rodaków fatalną opinię, jako rzecznik stanu wojennego i symbol dławienia dążności narodowych. Jego dymisję przyjęto z ulgą; „Ilustrowany Kurier Codzienny” pisał, iż ustąpienie tego „satrapy” oznacza „koniec gwałtów i bezprawia” i otwiera możliwość rozpisania wyborów parlamentarnych. Konkluzja mówiąca, że „dwie sprężyny niepokojów wyrzucone zostają na śmietnisko nieużytków", odnosi się do Lukácsa i Cuvaja ${ }^{15}$.

Koniec maja, początek czerwca 1913 roku. Redl, Lukács, Klofácz, Cuvaj. Austriak $^{16}$, Węgier, Czech, Chorwat. Kwartet mocno personalizujących się spraw o istotnym ciężarze politycznym, z Bałkanami w tle. W momencie chwilowego odprężenia, ale już z zaostrzającym się konfliktem serbsko-bułgarskim, nieuchronnie prowadzącym do wybuchu II wojny bałkańskiej. Na razie póki co, wraz z tego konse-

${ }^{15}$ Artykuł Dymisje dwóch tyranów, „Ilustrowany Kurier Codzienny” 1913, nr 129 (7 czerwca), S. 2 .

${ }^{16} \mathrm{~W}$ prasie polskiej nie funkcjonuje pojęcie narodowości austriackiej. Redl jest dla niej po prostu Niemcem, Niemcem austriackim. 
kwencjami politycznymi - zwłaszcza w Galicji - mówi się w trybie czasu przeszłego o „dobie niedawnego kryzysu”, „,chwilach przedwojennych”, „,niedawnym przesileniu” czy „czasach mobilizacyjnych”. Ale w monarchii Habsburgów, choć odnosi ona sukcesy na polu polityki międzynarodowej (wykreowanie Albanii), kipi wewnątrz od nagromadzonych napięć i nierozwiązanych (może nierozwiązalnych) problemów. Ich spektakularnym wykładnikiem są pokrótce scharakteryzowane afery, które odsłoniły horyzont zagrożeń dla spójności Austro-Wegier, moralne nadwerężenie jej ustroju i instytucji państwowych. To i tak było widoczne, ale stało się jeszcze bardziej wskutek symbolicznej personalizacji owego Zła, o którym pisał „Czas”.

Wydaje się zasadne wyróżnienie pięciu pól, w których ramach prasa polska komentowała polityczne wątki afery Redla. Pierwsze spośród nich ogniskuje się w ekspozycji psychopolitycznego uczucia trwogi i zgrozy, powstałego na podłożu nagłego zdania sobie sprawy przez opinię publiczna, jak bezradne i obezwładnione wskutek akcji szpiegowskiej byłyby Austro-Węgry w razie ich udziału w wojnie na Bałkanach czy w starciu zbrojnym z Rosją. Drugie to komentarze podkreślające upadek prestiżu na arenie międzynarodowej c. k. Monarchii, nadwerężenie moralnych jej fundamentów. Trzecie pole niesie z sobą treści politycznej krytyki korpusu oficerskiego. Czwarte obejmuje obszar dyskusji nad kwestią narodowości Redla, natomiast piąte, najważniejsze, to pole namiętnych polemik wokół ruchu niepodległościowego, z jednej strony obrony jego racji, zaś z drugiej gwałtownych nań ataków z powodu jego jakoby wywiadowczo-prowokacyjnego rodowodu. W ramach czterech pierwszych pól artykułowane poglądy polityczne nie są specjalnie kontrowersyjne, na piątym zaś dochodzi do ostrego starcia, któremu początek dała prasa warszawska, a zwłaszcza „Gazeta Poranna 2 Grosze”. Względna niekontrowersyjność niekoniecznie wynika $\mathrm{z}$ podobnego punktu widzenia. Za zbliżoną w swojej wymowie tezą kryją się bowiem nieraz różne intencje i towarzyszy im inna argumentacja. Na przykład przypisywane Austro-Węgrom polityczne kunktatorstwo, gra na zwłokę, odraczanie spraw istotnych kosztem drobnych posunięć dla niepodległościowców jest powodem irytacji, a dla endeków źródłem satysfakcji potwierdzającym ich rację polityczną, że nie warto wiązać się z tak słabym państwem, niezdolnym nawet do partnerowania Niemcom. Cała prasa polska dementuje pojawiającą się $\mathrm{w}$ gazetach wiedeńskich informację, że Redl był Polakiem, ale dzienniki poznańskie czy śląskie podkreślać będą w szczególności to, że z pochodzenia był Niemcem, ale o usposobieniu hakatysty (w Galicji i w Królestwie też się o tym pisze). „Dziennik Poznański” dementuje „fałsze wierutne” o polskim pochodzeniu Redla, „by z góry zapobiec twierdzeniom pojawiającym się w gazetach niemieckich”"17, zaś „Katolik”, by dać odpór „gazetom hakatystyczny$\mathrm{m}^{\prime 18}$. Natomiast prasa warszawska o barwie endeckiej podniesie kwestię żydowskie-

17 „Dziennik Poznański”1913, nr125 (4 czerwca), s. 4 w passusie Kroniki, zatytułowanym Jakiej narodowości byt pułkownik Redl. Tamże mowa o naturze tego szpiega, jako zbrodniczej, szatańskiej i nikczemnej.

18 „Katolik” 1913, nr 69 (10 czerwca), s.1 w artykule wstępnym Sprawa Redla. Pułkownik został tu określony mianem „najniebezpieczniejszego zbrodniarza” i „potwora najwstrętniejszego, jacy rzadko na świat przychodzą". 
go pochodzenia Redla, a wtórować jej będą związane z Narodową Demokracją dzienniki galicyjskie i poznańskie.

Funkcjonalność wyodrębnionych pól, z uwypuklającymi się na nich wątkami komentarza politycznego, omówimy przybliżając sposób przedstawiania afery Redla w dziennikach i pismach periodycznych. Najbardziej intensywny i najszerszy kontekst sensacji $\mathrm{w}$ opisywanej sprawie zostanie uwzględniony, ale naturalnie tylko w niezbędnym dla podjętego tematu wymiarze. Niekiedy i on ma swoje znaczenie quasi-polityczne, wówczas gdy prasa mnoży pogłoski o aresztowaniach w związku z tą aferą oficerów, osób cywilnych czy pewnej „wybitnej osobistości” w Wiedniu, Pradze, Budapeszcie, Grazu, Krakowie czy Lwowie. Kojarzy się to z jakimś rodzajem histerii czy psychozy, zagęszczającą atmosferę podejrzeń, dobrą dla prasy, ale źle świadczącą o kondycji państwa. Niejako równolegle krążą w formie sugestywnych pogłosek oskarżenia kierowane pod adresem konsulatów rosyjskich w Wiedniu i Pradze, jako placówkach szpiegowskich, infiltrujących Austro-Węgry. Podaje się nazwiska wydalanych dyplomatów, ale przeważnie okazuje się, że są to plotki, dementowane przez Rosjan, także w formie not kierowanych do ministerstwa spraw zagranicznych. Niemniej czytelnikom gazet wydaje się, że odbywają się masowe aresztowania wśród oficerów c. k. armii, a placówki dyplomatyczne ościennego mocarstwa są wyłącznie agenturami szpiegowskimi. Na wyobraźnię sybillińską odbiorców nic nie oddziałuje mocniej niż teorie spiskowe, a przecież nikt nie wątpi w to, że Redl stał na czele rozgałęzionej siatki szpiegów (których trzeba wykryć i aresztować) i że każdy dyplomata rosyjski to agent obcego wywiadu. Prasa odpowiedziała na to psychologiczne zapotrzebowanie czytelnicze. A informację o objęciu ,ścisłym dozorem policyjnym" Rosjan zamieszkałych w Wiedniu i Pradze pozostawia się bez komentarza, bo sprawa wydaje się oczywista. To też pewien efekt szerzącej się psychozy, choć nie ma on tej rangi, co na przykład aresztowania oficerów i wydalenia dyplomatów. Czytelnika nie dziwią też informacje o samobójstwie kilku oficerów sztabu generalnego i ministerstwa wojny w Rosji, jako skutku zdemaskowania czy raczej obaw o zdemaskowanie w związku z aferą Redla. To również wydaje się oczywiste.

Urzędowa „Gazeta Lwowska” podawała bardzo powściagliwe informacje o „sprawie b. pułkownika Redla" (już ta formuła świadczy, iż redakcja chciała uniknąć użycia choćby określenia „afera”). Po podaniu informacji, iż szef sztabu generalnego VIII korpusu w Pradze pułkownik Alfred Redl ,prawdopodobnie popełnił samobójstwo w przystępie obłędu" w numerze 118 (27 maja), następuje kilkudniowa przerwa w kontynuowaniu tego tematu. Natomiast poczynając od numeru 121 (30 maja) pojawiają się treści interpelacji reprezentantów Izby posłów w Wiedniu, kolejno: Naumanna, Breitera, Wassilki, Miklasa, Hausera, i Grossa. Brakuje głosów polskich w tej sprawie, choć z drugiej strony swoją wagę ma wystąpienie prezesa Koła polskiego, podobnie jak mowa Ignacego Daszyńskiego, w której dowodził, że nie będzie nieszczęścia, jeśli procesy zapoczątkowane wskutek wojny na Bałkanach doprowadzą do powstania państw narodowych. Jednakże, biorąc pod uwagę odpór dawany prasie wiedeńskiej z powodu rzekomo polskiego pochodzenie Redla, powinno to sprowokować interpelację w tej sprawie. Ważnym źródłem nie tylko informacji, ale i stylu in- 
formowania jest dla „Gazety Lwowskiej” „Militärische Rundschau”, urzędowy organ armii austro-węgierskiej, który nawoływał do powściągliwości wobec szerzących się „awanturniczych pogłosek” i dementował wiadomości podające w wątpliwość morale oficerów sztabu generalnego (na przykład tę, że Redl miał jakieś z nimi związki). Streszczenie wystąpienia ministra obrony krajowej Georgiego zamieszczone w numerze 127 (6 czerwca) kończy sekwens informacyjny o pułkowniku Redlu, choć tydzień później odnotowane jeszcze zostają głosy w tej sprawie, ale zabrane w komisjach sejmowych. Jest to ucięcie sprawy godne organu urzędowego, choć w całej prasie polskiej mnożą się komentarze na temat sensacyjnej afery. W podobnie oschłym trybie informowania czytelnika przedstawiana jest „sprawa Lukácsa-Desy’ego”, odwołanie bana Cuvaja i utworzenie nowego gabinetu hr. Tiszy. Odnotowane zostało kilka drobniejszych spraw, zakończonych zarzutem szpiegostwa na rzecz Rosji bądź procesem karnym (na przykład przeciwko Józefowi Gądkowi i Zofii Linkównie). Niekoniecznie miały one przesłaniać aferę Redla, gdyż temat szpiegostwa należał do standardów informacyjnych nie tylko w prasie sensacyjnej.

Konserwatywny krakowski „Czas”, ukazujący się codziennie w wydaniach porannym i popołudniowym, przyjął zrazu podobną taktykę, jak "Gazeta Lwowska”, by po kilku dniach jednak zogniskować uwagę na "sprawie Redla” (starannie stosowano tę formułę, raz tylko i to w cudzysłowie, będącym oznaką dystansu, mowa jest o ,aferze”). Już w numerze 236 (26 maja, wyd. popołudniowe) w rubryce Telegramy „Czasu” pojawia się informacja o popełnieniu przez pułkownika Redla samobójstwa „prawdopodobnie w przystępie obłędu”. W tym samym numerze odnotowano skazanie za szpiegostwo w zakończonym procesie we Lwowie byłego pułkownika armii rosyjskiej Jucewicza i aresztowanie w Sewastopolu majora Goli, japońskiego attaché wojskowego w Berlinie. Dopiero w numerze 243 (30 maja, wyd. poranne) redakcja „Czasu” wraca do uprzednio wzmiankowanego tematu samobójstwa, ale za to w osobnym tekście zamieszczonym na pierwszej stronie gazety. Tłumaczy czytelnikom, że jak na poważny dziennik redakcja wstrzymywała się „od notowania tych pogłosek". Wskazane to byłoby i prasie polskiej, z tego powodu - to zadziwiająco niedorzeczna argumentacja - że urodzony we Lwowie pułkownik Redl był synem wysoko postawionego urzędnika kolejowego. Pogłoski niestety, ubolewa redakcja, się sprawdziły, i co do tego nie może być wątpliwości, gdyż źródłem informacji jest „Militärische Rundschau”. Do zdrady popchnął Redla szantaż „na tle seksualnym”.

Kolejne numery dziennika przynoszą bogaty serwis informacji, opatrzony niekiedy komentarzami. W głównej mierze bierze się on z przedruków prasy wiedeńskiej („Neue Freie Presse”, „Wiener Zeitung”, „Wiener Allgemeine Zeitung”, „Zeit”, „Militärische Rundschau”, „Fremdenblatt” i inne), praskiej („Narodni Listy”, „Bohemia”) i budapeszteńskiej. Głównym źródłem informacji agencyjnych, co nie znaczy wyłącznym, jest natomiast półoficjalne biuro Wolfa. W „Czasie” pisze się więc obficie o kulisach samobójstwa pułkownika (cytuje się jego pożegnalny list do brata), tajnej komisji wojskowej, postępach śledztwa i szokujących wynikach rewizji mieszkania Redla w Pradze, powiększającym się kręgu osób podejrzanych, zapowiadanych dymisjach, roli konsulów rosyjskich, kamuflażu szpiegowskim w wynaję- 
tym lokalu w Wiedniu, elementach biografii zdrajcy i jego eskapadach do Warszawy, o reakcji cesarza Franciszka Józefa po zapoznaniu go z aferą i wielu innych sprawach, które mogły interesować czytelnika. Podawane są fakty (prasowe) i przypuszczenia, a w serwisach informacyjnych przewijają się dziesiątki nazwisk. Nie sposób ich wyliczać bez odejścia od tematu.

Nastawienie na informacje nie oznacza rezygnacji ani z komentarza ani z akcentów krytyki. Dość typowy pod tym względem jest tekst korespondencji z Wiednia Po sprawie Redla, zamieszczony na s. 1 numeru 248 (2 czerwca, wyd. popołudn.). Według jego autora (korespondenci byli anonimowi) za przesadny należy uznać pogląd, że zdrada Redla mogłaby być przyczyną klęski w razie wojny Rosji z AustroWęgrami, gdyż pułkownik miał ograniczoną wiedzę na temat c. k. armii (wiedział wszystko tylko o korpusie, w którym służył). Ostro natomiast - ale prawdę mówiąc, najzupełniej $\mathrm{w}$ zgodzie $\mathrm{z}$ oficjalnymi interpelacjami poselskimi - zaatakowane zostały władze wojskowe za sprowokowanie śmierci samobójczej pułkownika, i tym samym uniemożliwienie wyjaśnienia sprawy do końca, co było sprzeczne z interesem państwa. Rycerska tradycja honoru stanęła, więc, na drodze powszechnego poczucia sprawiedliwości. Korpus oficerski powinien zrozumieć, że „,armia nie jest już od dawna społeczeństwem w społeczeństwie” (dziś powiedzielibyśmy: „państwem w państwie").

Komentowana jest odpowiedź na interpelacje poselskie ministra Georgiego, z zaznaczeniem negatywnego do niej nastawienia parlamentarzystów czeskich i ugrupowań socjalistycznych. Nie odnotowano natomiast reakcji Koła polskiego, które, jak wiadomo, było jednak za wnioskiem ministra o niedyskutowanie jego wystapienia. W numerach 254 (5 czerwca, wyd. popołudni.) i 256 (6 czerwca, wyd. popołudniowe) pojawiają się przedrukowywane za prasą lwowską wypowiedzi Polaków, którzy zetknęli się z Redlem, służąc w 9. i 30. pułku piechoty. Konkluzja tych i innych opinii (profesora Mariana Signo) jest taka, że Redl pochodził z rodziny czysto niemieckiej, a jego znajomość języków słowiańskich (rosyjskiego, polskiego i ukraińskiego) wzięła się z nauki, co znakomicie dopomogło mu w karierze w biurze ewidencyjnym.

Niejako w trybie równoległym opisywana jest sprawa Lukácsa, rozgrzeszanego zresztą ,Z wyższego punktu widzenia” jako polityka, który - podobnie jak Tisza - miał odwagę wydać wojnę „hydrze” opozycyjnej obstrukcji. Odnotowano też bez większych emocji dymisję Cuvaja i opisano perypetie posła Klofácza. Niemało miejsca zajmował niemal codzienny opis ,audiencji powitalnych” namiestnika Korytowskiego. Zabrakło natomiast jakichkolwiek odniesień do sytuacji, w jakiej znalazł się ruch strzelecki, o którym wzmianka znalazła się nawet w przywoływanym już wystąpieniu prezesa Koła polskiego w Wiedniu.

„Nowa Reforma”, gazeta krakowska wywierająca wpływ na znaczną cześć opinii publicznej, uważnie śledziła przebieg afery Redla, opatrując jej wątki komentarzem politycznym. Redakcja nie wahała się zamieszczać obszernych serwisów informacyjnych na pierwszych stronach wydań porannych i popołudniowych, a uwage czytelnika zwracały tytuły, określające aferę szpiegowską, jako „,sensacyjną”, „wielką” czy „wprost niebywałą". Mocną stroną doniesień była rubryka Telefoniczne i te- 
legraficzne wiadomości „,Nowej Reformy”, w której zamieszczano informacje własne z Wiednia. Bywało, że teksty publikowane w tym dzienniku przedrukowywała prasa warszawska, na przykład „Kurier Warszawski”. „Nowa Reforma”, podobnie jak inne pisma, czerpała jednak najwięcej z doniesień gazet wiedeńskich i praskich, ale wyróżniał ją pewien dystans do tego rodzaju źródeł informacji. Na przykład przedrukowana za jednym $\mathrm{z}$ dzienników wiadomość o aresztowaniach w Krakowie w związku $\mathrm{z}$ aferą Redla, przeważnie przedrukowywana bez zastrzeżeń, choć ewidentnie wyglądała na pogłoskę, opatrzona zostaje tytułem „Niesprawdzona informacja” i zastrzeżeniem:

(Wiadomość tę podajemy na odpowiedzialność N. W. Tagblattu Przyp. Red.) ${ }^{19}$.

„Nową Reformę" wyróżniało ponadto doskonałe panowanie nad masą informacyjną. Inne gazety poprzestawały na umieszczaniu w wyodrębnionym bloku tematycznym (w tym wypadku dotyczącym afery Redla) po prostu luźnego serwisu wiadomości spływających z biur korespondencyjnych i dzienników zagranicznych. Natomiast „Nowa Reforma” te wiadomości umiała rozdysponować na części, nadając im zwracające uwagę czytelnika podtytuły. Przykładem jest blok tematyczny Wielka afera szpiegowska w Austrii w numerze 244 (wieczornym) z 31 maja, podzielony na fragmenty zatytułowane: Whotelu Klomsera, Samobójstwo. Browning na stole, Rozmiary zdrady, Procedura honorowa, Geneza zbrodni, Redl w Pradze, Interpelacja. Można powiedzieć, iż w tym wypadku mamy do czynienia z przemyślaną i atrakcyjną organizacją tekstu prasowego.

Pierwsze doniesienia są najzupełniej obiegowe, przeważnie powtarzane za praską „Bohemią”, a dotyczą one szczegółów zdemaskowania Redla i jego samobójczej śmierci. Do tego dochodzą elementy związane z wojskową karierą pułkownika (między innymi jego pobyt w Berlinie podczas „,przesilenia aneksyjnego”). Pojawia się też informacja natury obyczajowej o samobójczej śmierci kamerdynera Redla, należącego do ,indywiduuów”, biorących udział w ,orgiach homoseksualnych”.

Redakcja nie stroniła od komentarzy, niekiedy formułowanych na kanwie doniesień telefonicznych z Wiednia, uzyskiwanych od własnego korespondenta. Podzielając powszechną w prasie krytykę władz wojskowych, których postawa uniemożliwiła postawienie „zbrodniarza” pod sąd, pisano:

Już czas najwyższy, aby w „ludowej” armii austro-węgierskiej rzeczywiście obowiązywał nowy kodeks karny, zastosowany do nowoczesnych pojęć o procedurze sądowej i prawach obywatelskich ${ }^{20}$.

C. k. Monarchia składała się z „ludów”, więc chociaż przymiotnik wzięty w cudzysłów ma w sobie coś z przekąsu, pozostaje najzupełniej poprawny politycznie. Nawiasem mówiąc, inaczej mają się sprawy, kiedy „ludowy” zastępuje się „narodowym”. Przykładem jest komentarz ukazującego się również w Krakowie „Głosu

19 „Nowa Reforma” 1913, nr 246 (wieczorny), s. 4.

20 „Nowa Reforma” 1913, nr 244 (wieczorny), s. 3. 
Narodu", w którym Redla zaliczono do licznej w armii austriackiej kategorii oficerów „pod względem narodowym zupełnie obojętnych”, nastawionych wyłącznie na karierę ${ }^{21}$. Dowództwo armii wyraźnie uprzedzone jest do oficerów, mających poczucie przynależności narodowej, stąd bierze się ich niewysoka pozycja w hierarchii wojskowej. Nauka z afery Redla jest taka, że nastąpić musi zmiana stosunku przełożonych do oficerów „narodowych” (cudzysłów w oryginale), gdyż ich morale oparte jest na najmocniejszym fundamencie, jaki jest „narodowe uczucie”. Oficer Polak, patriota twierdzi komentator - nigdy nie dopuściłby się zdrady.

Natomiast „Wielkopolanin”, kpił sobie z szefa sztabu armii austro-węgierskiej barona Hötzendorfa, który starał się zreformować korpus oficerski „na modłę pruską". Sprawa Redla wykazała kompromitację tej metody musztrowania armii, podobnie jak klęska wojsk tureckich, szkolonych przez feldmarszałka Goltza ${ }^{22}$, w wojnie na Bałkanach.

Komentując sprawę zachowań oficerów po oskarżeniu ich przez służby kontrwywiadowcze, „Nowa Reforma” wzmiankuje o sprawie Dreyfusa. Przyłapany na fałszowaniu dokumentów pułkownik Henry, podczas pobytu w Wiedniu popełnił samobójstwo za pomocą brzytwy. Ale bardziej adekwatną analogię zastosować można do Hofrichtera, któremu po jego aresztowaniu do szuflady włożono rewolwer, ale ten w nadziei oczyszczenia się z zarzutów, nie zdecydował się pozbawić siebie życia.

Obszerny blok telefonicznych informacji z Wiednia przyjmuje postać artykułu wstępnego, zatytułowanego Niebywała afera szpiegowska $w$ Austrii, opublikowanego na s. 1 numeru porannego 245 z 31 maja. Na czoło wysunięto wiadomość o tym, w jaki sposób, po wykluczeniu podejrzeń, że wysoko postawiony szpieg operuje w korpusie stacjonującym w Litomierzycach, uwaga kontrwywiadu austriackiego, skierowała się na VIII korpus w Pradze, którego szefem sztabu był Redl. Dowód uzyskano wskutek wydania fałszywego okólnika przez dowódcę korpusu praskiego i analizę kontrposunięć armii rosyjskiej.

Wyolbrzymia się rolę Redla jako agenta, który był w stanie nie tylko wpływać na działania wojenne czy raczej mobilizacyjne c. k. armii, ale je wręcz paraliżować:

Istotnie Redl był tym, który w czasie ostatniego przesilenia paraliżował wszelką akcję wojskową Austrii, tak samo jak i w czasie przesilenia aneksyjnego, kiedy to zajmował również wybitne stanowisko w armii austriackiej.

W tym kontekście wysuwane jest podejrzenie odnoszące się do „p e w n e j o s obistości w Galicji" (rozstrzelony druk jak w oryginale), powiązanej blisko z Redlem, która ma być agentem rosyjskim. Nie wyjaśniono później, o jaką to osobistość chodzi, co pozostawiało pewien niedosyt, ale zakrawająca na sensację wiadomość zdawała się mieć jakiś pozór prawdopodobieństwa. A jeśli na to podejrzenie powoływała się prasa Królestwa, na przykład „Kurier Warszawski”, czytelnik mógł

21 „Głos Narodu” 1913, nr 125 (4 czerwca), s. 1 (w rubryce Korespondencje).

22 Szpieg, ,Wielkopolanin” 1913, nr 123 (1 czerwca), s. 1. 
sobie dopowiedzieć: no tak, jeśli „Nowa Reforma” tak pisze, to zapewne jest coś na rzeczy w oskarżeniach polityków galicyjskich i ,aktywistów” co najmniej o uleganiu przez nich prowokacji. Liczba pojedyncza w walce politycznej łatwo staje się liczbą mnogą.

W numerze wieczornym dopowiedziano, iż Redl nie tylko sparaliżował akcję militarną (mobilizacyjną) Austro-Węgier podczas wojny na Bałkanach, ale i zdradził Rosji agentów austriackich w armii carskiej. Z drugiej strony w hotelu Klomsera miał on wydać listę agentów rosyjskich operujących w c. k. armii. Podano szereg informacji i pogłosek dotyczących między innymi nurtującego prasę wiedeńską pobytu w tym hotelu w dniu samobójstwa Redla, jego przyjaciela, dra Pollaka, generalnego adwokata i prokuratora Najwyższego Trybunału, a także dochodzenia prowadzonego przez majora audytora Worliczkę i kapitana audytora Mayerbacha, które jakoby potwierdziło, iż Redl wydał Rosjanom plan dyslokacyjny i mobilizacyjny Niemiec.

Kluczowy w odniesieniu do afery jest numer 248 (popołudniowy) z 2 czerwca, w którym na s. 1 zamieszczono obszerny komentarz redakcyjny Rozmiary sprawy Redla, i jak zwykle umiejętnie rozdysponowany serwis informacyjny, zatytułowany Szpiegostwo putkownika Redla. Komentarz wiąże sprawę Redla z wojną na Bałkanach, jako właściwie jeden z jej epizodów, który nieoczekiwanie zmienił punkt widzenia na wypadki zszokowanej opinii publicznej:

Po bolesnej klęsce dyplomatycznej, jaką poniosła Austria podczas całej zawieruchy bałkańskiej, niby jeden z jej epizodów, zaskoczyła zdenerwowaną już dostatecznie opinię publiczną afera szpiegowska pułkownika Redla, i wywołała wrażenie piorunujące. Wszyscy mają odczucie, że Austria stała na wulkanie, przed którego wybuchem szukałaby była schronienia, w fałszywym uciekając kierunku. Całe pogotowie wojenne i różnej kategorii mobilizacje, które nie tylko same ogromne pochłonęły sumy, lecz jeszcze większe wywołały szkody materialne na polu finansowym i ekonomicznym, były, jak powszechnie przypuszczaja, przedmiotem transakcji szpiegowskiej i nie chroniły państwa austriackiego, w razie wybuchu wojny, w tym stopniu, jak tego mieliśmy prawo wyczekiwać.

Rozmiary sprawy Redla - czytamy w komentarzu - cechuje „przykra niepewność", niewiedza, w jakim zakresie i w jakim stopniu tajemnice wojskowe AustroWegier przeniknęły do „ościennego państwa”. Fatalne w skutkach i skrajnie krótkowzroczne okazało się nakłonienie pułkownika do samobójstwa. Zeznający w śledztwie i postawiony przed sądem Redl, jak to obrazowo ujęto w komentarzu, przedstawiałby o wiele większą wartość, niż leżąc $\mathrm{w}$ grobie. Tej i podobnym opiniom towarzyszy pełen wzburzenia apel o wyjaśnienie wszystkich aspektów afery szpiegowskiej, gdyż z punktu widzenia prawa i sądownictwa wojskowego jest to „kwestia zasadnicza, tworząca niesłychanej wagi precedens na przyszłość”. Machina kontrwywiadowcza kompletnie zawiodła, pomimo rzucającego się w oczy rozrzutnego trybu życia Redla, co natychmiast po jego śmierci wyszło na jaw, a winno wyjść znacznie wcześniej. Redakcja dodaje:

Na tych paru uwagach na razie poprzestajemy, zastrzegając sobie głos, gdy wykryją się dalsze szczegóły tej tajemniczej, charakteru i rozmiarami swymi niesłychanej afery. 
Komentarz niejako uzupełnia informacja podana za „Korrepondenz Austria” o napiętnowaniu przez posłów Zjednoczenia Chrześcijańsko-Społecznego w Wiedniu „systemu zacierania” (Vertuschungssystem), który polegał na zmuszeniu pułkownika Redla do popełnienia samobójstwa w celu zatuszowania afery.

Obok komentarza umieszczono obszerny serwis informacyjny Szpiegostwo putkownika Redla, podzielony na fragmenty noszące intrygujące tytuły np. Tajemnicza dama. - Stefan Horinka, z których dwa odnoszą się do spraw polskich: Redl zdradza towarzystwa strzeleckie i Redl w Warszawie. Mowa w nich o „obszernym i wyczerpującym elaboracie" Redla na temat stosunku austriackiego ministerstwa wojny do ruchu strzeleckiego, który posłużył rosyjskiemu Ministerstwu Spraw Zagranicznych, jako materiał do interwencji dyplomatycznej w Wiedniu, a także o pobytach pułkownika w Warszawie, jego hulaszczym trybie życia i utrzymywaniu „bliższych stosunków przyjaźni" z generałem Miszczenką, pełniącym wcześniej funkcję attaché wojskowego ambasady rosyjskiej w Wiedniu.

W tym samym numerze dziennika odnotowano też przypuszczenia gazet czeskich odnośnie do możliwości wyjazdu konsula rosyjskiego Żukowskiego z Pragi z powodu jego uwikłania w aferę szpiegowską i o samobójstwie kilku wysoko postawionych oficerów rosyjskich, jako konsekwencji zdrady Redla.

W numerze 249 (porannym) z 3 czerwca dominuja informacje telegraficzne z Wiednia, ciagle jeszcze umieszczane na s. $1 \mathrm{w}$ wyodrębnionej tematycznie rubryce Szpiegostwo Redla. Doniesienia są standardowe, a mowa w nich między innymi o stanowczym podtrzymywaniu przez dzienniki praskie opinii, iż Redl wydał Rosji „ordre de bataille” armii niemieckiej na wypadek wojny z Rosją, i o konieczności przebudowy fortyfikacji austriackich. A w następnym numerze podane jest doniesienie „Neue Wiener Tagblatt”, iż Redl przekazał Rosji plan przygotowań wojennych Austro-Węgier w Galicji, Bośni i Dalmacji.

W numerze 251 (porannym) z 4 czerwca telefoniczne doniesienia z Wiednia są nader lakoniczne, a nadanie im tytułu Echa afery Redla, znamionuje schyłek zainteresowania sprawa, choć ciagle gości ona jeszcze na pierwszej stronie dziennika (przesłania ją teraz sprawa Lukácsa i bulwersujące doniesienia z parlamentu węgierskiego). Tak samo jest w 253 numerze (porannym) „Nowej Reformy”, w którym na s. 1 nieokazały tekst Echa afery Redla (tu informacja o wywiadzie udzielonym „Bohemii” przez konsula rosyjskiego Żukowskiego w Pradze i o jego zażaleniu złożonym władzom austriackim na kierowane wobec niego zarzuty o współpracę z Redlem) sąsiaduje z obszernym serwisem informacyjnym zatytułowanym Skandaliczne zajścia $w$ parlamencie wegierskim, z podziałem na sekwencje tematyczne: Manifest Justha, Lukacs o swoim ustapieniu, Sprawozdanie kapitana Goëre, Przesilenie gabinetowe, Prasa o zajściach. W szczegółach odnoszących się do tego skandalu przytaczane są okrzyki wznoszone przez posłów opozycyjnych: „Gwardia Redla! (poseł Husar pod adresem debiutującej straży parlamentarnej), „Niech żyje armia!” (poseł Dezyderiusz Polonyi ironicznie o c. k. armii, skompromitowanej wskutek afery Redla). W taki sposób nazwisko pułkownika - nabierając treści symbolicznych - niesłychanie szybko przenosi się z Wiednia i Pragi do Budapesztu. 
W kolejnych numerach „Nowej Reformy” doniesienia o aferze szpiegowskiej są raczej marginalne i ograniczają się do szczegółów (zwraca uwagę rzadkie powołanie się na prasę rosyjską). Wyjątkiem, ale równocześnie w zasadzie zamykającym temat, jest dokładne omówienie treści odpowiedzi na interpelacje poselskie ministra obrony krajowej Georgiego w numerze 255 (porannym), i o ostrej reakcji prasy wiedeńskiej na to niesatysfakcjonujące wystapienie w numerze 256 (popołudniowym).

Aferze Redla najwięcej uwagi poświęcił nastawiony na sensację „Ilustrowany Kurier Codzienny”, który jednak - w przeciwieństwie do „Gazety Lwowskiej” i „Czasu” - nie miał zahamowań w kwestii politycznego jej komentowania. Pod tym względem wyprzedził prasę galicyjską (oczywiście nie do końca i nie we wszystkim, czego przykładem jest „Nowa Reforma”), a zwłaszcza ten jej odłam, który sprzyjał ruchowi strzeleckiemu i dał się zaskoczyć argumentacji przeciwnika politycznego. Można nawet postawić tezę, że nie wykorzystano śmiałych komentarzy „Ilustrowanego Kuriera Codziennego", które wprawdzie ukazywały ruch strzelecki w kontekście afery Redla, ale jako jej ofiarę i podnosiły znaczenie tego ruchu w powstrzymaniu Rosji od agresji na Austro-Wegry. Dziennik wykazał perswazyjną inteligencję w stopniu o wiele wyższym niż tak zwane poważne pisma, które niekiedy wybierały taktykę przemilczenia, by przywołać tu konserwatywny „Przegląd Polski”, czy „Przyjaciela Ludu”, organ PSL-u. „Ilustrowany Kurier Codzienny” wyprzedził również prasę warszawską, ale ta po głośnych komentarzach „Gazety Codziennej 2 Grosze” przejęła inicjatywę i zmusiła do przyjęcia linii obrony przez sprzyjającą działalności Komisji Tymczasowej część prasy galicyjskiej, czego przykładem jest reakcja na „dwugroszówkę" zorientowanej niepodległościowo "Krytyki". Najpoważniejsze wystąpienie polityczne w sprawie afery Redla, a mianowicie artykuł Zygmunta Balickiego zamieszczony w „Przeglądzie Narodowym”, o którym będzie jeszcze mowa, bazował właśnie na sensacjach „Gazety Porannej 2 Grosze”. Zatem i „ikac” i „dwugroszówka” odegrały niebłahą rolę w uruchomieniu politycznego myślenia na temat afery Redla. Nauka z tego jest i taka, że nie należy lekceważyć prasy codziennej i jej jaskrawych politycznych nastawień, nawet jeśli sensem jej istnienia jest pogoń za sensacją. To, o czym nawet nie pomyśli wytrawny czy zbyt wytrawny statysta, ogół ma już na swoich ustach. Ciekawe, że nie, dajmy na to, „Czas”, ale „Ilustrowany Kurier Codzienny” mógł przechwalać się przedrukami swoich komentarzy w „dziennikach tak poważnych” jak „Zeit”, Tagblatt”, „Arbeiter Zeitung” i „Deutsches Volksblatt”, co triumfalnie zakomunikowano.

Ale wróćmy do „Ilustrowanego Kuriera Codziennego”, który przez kilka dni informował o aferze w sposób konwencjonalny. W numerze 119 (27 maja) podano, iż powodem samobójstwa Redla było ,przepracowanie wskutek wzmożonej pracy sztabu, spowodowanej sytuacją zagraniczną". W następnych zaś mowa jest o tym, iż był on „najniebezpieczniejszym szpiegiem rosyjskim”, co znajduje oficjalne potwierdzenie w „Militärische Rundschau”. Dopiero numer 125 (3 czerwca) przynosi z sobą istną eksplozję informacji, zaopatrzonych w komentarz. Można by go nazwać numerem specjalnym, gdyż niemal w całości poświęcony on został aferze Redla. Na stronie tytułowej pod sugestywnym rysunkiem umieszczono krzyczący podpis: Wyprowadzono 
by nas na pewnq rzeź!. Wyprowadzono by - taki był jego sens - nas Polaków i c. k. armię, gdyby wojna na Bałkanach przekształciła się w wojnę Rosji z Austro-Węgrami. Rzeź pewną, bo zdrada Redla, „niesłychana, niepojęta, potworna” (redaktor dobiera intensywne przymiotniki), niechybnie by do niej doprowadziła. Tu w grę wchodziły także „nasze losy”, narażone na szwank wskutek „,skandalicznej opieszałości” austrowęgierskiego sztabu generalnego. Poderwano zaufanie monarchy i rządzonych przez niego ludów, które ofiarnie zaspokajały wszelkie potrzeby wojskowe.

I tu następuje efektowna figura myśli, zbudowana na hipotezie, dlaczego Rosja nie zdecydowała się na wojnę, mając przed sobą wskutek zdrady całkowicie odsłoniętego przeciwnika. Dlatego, thumaczy komentator, że Rosję powstrzymała obawa przed największą niewiadomą, jaką jest kwestia polska. Imperium zawahało się przed tym, co nie da się ując za pomocą liczb, i tym, co wiecznie spędza i spędzać będzie mu sen z oczu.

Rosja ulękła się polskiego ruchu zbrojnego, ulękła się obudzonej wypadkami bałkańskimi z letargu duszy polskiej żyjącej pragnieniem zemsty na swym śmiertelnym wrogu i ukochaniem idei niepodległości ojczyzny (s. 2).

Autor komentarza ${ }^{23}$ puentuje swoją efektowną myśl akcentem przygany wobec c. k. Monarchii, której głównym celem politycznym winna być nie południowa Słowiańszczyzna, ale zwalczanie Rosji, określanej tu tradycyjnym mianem „tyrana północy".

W numerze 126 (4 czerwca) zwraca uwagę notka Denuncjator polskich towarzystw strzeleckich, której tytuł zręcznie pod względem perswazyjnym figuruje Redla, jako delatora, ale nie oficera wywiadu w jakiś sposób współpracującego z ruchem. Nie jest on tu prowokatorem, ale donosicielem piszącym „elaboraty”, które wywoływały i ten skutek, że w sprawie związków strzeleckich rosyjskie ministerstwo spraw zagranicznych interweniowało w Wiedniu (s. 3). Zatem zdrajca Redl nie ma nic wspólnego z tymi związkami, których czystość tym samym pozostaje poza wszelkimi podejrzeniami. Jednak nie postawiono tu pytania, skąd brała się wiedza Redla umożliwiająca pisanie mu tak obszernych elaboratów. W tym kontekście swój asekuracyjny sens ma wyrażone przypuszczenie, iż „nie jest wykluczone”, że „w czasach mobilizacyjnych” Redl przyjeżdżał do Lwowa.

Numer 127 (5 czerwca) „Ilustrowanego Kuriera Codziennego” również można uznać za numer specjalny z rysunkiem na stronie tytułowej Niebywała afera szpiegowska i krzyczącym podpisem Skandale w Austro-Wegrzech. Informacje i komentarze odnoszą się tu głównie do afery Redla i ,panamy wegierskiej”, czyli skandalu związanego z korupcją polityczną, jakiej dopuścił się premier Lukács, określany soczystym mianem „szachraja politycznego i korupcjonisty”. Jak widać, w przeciwieństwie do urzędowych czy nobliwych dzienników, „ikac” nie krępował się względami

${ }^{23}$ Być może był nim wydawca i redaktor naczelny Marian Dąbrowski, niedługo potem jeden z najzdolniejszych propagandystów Legionów. 
poprawności politycznej. Wymowa płynąca z zestawienia tego, co stało się w Austrii i na Węgrzech zawiera się w myśli, że afery Redla i Lukácsa „wstrząsnęły niemal podwalinami monarchii”. To „niemal” jest tu znaczące, gdyż komentator nie odczuwa Schadenfreude z powodu moralnej kompromitacji Austro-Węgier, a redakcja niejednokrotnie deklaruje postawę propaństwową. Tych zahamowań nie ma prasa warszawska. Diagnozy są podobne, ale intencje i rachuby polityczne całkiem odmienne.

„Ilustrowany Kurier Codzienny” odnosi się również do kwestii pochodzenia Redla. Podkreśla, jak cała prasa polska, jego niemiecką przynależność narodową, hakatystyczną nienawiść do Polaków. Z usposobienia Prusak (to brzmiało jak inwektywa), wyznania katolickiego (nr 125 z 3 czerwca). W następnym numerze na s. 6 podana jest informacja przedrukowana za „Ostdeutsche Rundschau”, że dziadek Redla był galicyjskim Żydem (przypuszczenie to robi furorę w prasie endeckiej). Nie do przyjęcia natomiast są spekulacje wyrażane nawet przez „oględniejsze” pisma niemieckie, że zdrajca był spolonizowanym Niemcem lub też zniemczonym Polakiem, albowiem był on po prostu hakatystą.

$\mathrm{Z}$ bogatych doniesień odnoszących się do afery Redla odnotować warto informację o szerzącej się pod jej wpływem manii prześladowczej, której ofiarą padło sześć osób we Lwowie. Zostali oni hospitalizowani w szpitalu psychiatrycznym; to niemal epidemia, konkluduje dziennik (nr 130 z 8 czerwca). Odnotowano też przypadek pewnego porucznika rezerwy, cierpiącego na manię prześladowczą, który w obawie przed posądzeniem go o związki z Redlem, usiłował popełnić samobójstwo ${ }^{24}$.

Przekonanie o wszechobecności szpiegów gruntowały ciagłe procesy, na przykład te odnotowane przez „Gazetę Lwowską" i „Czas”, „Nową Reformę” czy „Ilustrowany Kurier Codzienny”, w numerze 129 (7 czerwca) donoszący, że przed sądem krakowskim stanąć ma w najbliższych dniach liczna szajka szpiegów. Nawiasem mówiąc, te zdarzenia i towarzyszące im objawy manii prześladowczej były złowrogim sygnałem rzeczywistych, a niesłusznych posądzeń o szpiegostwo, kończącymi się natychmiastowym wykonaniem wyroków śmierci na niewinnej ludności w pierwszym roku wojny. Stefan Żeromski określił w związku z tym cesarza Franciszka Józefa mianem „wieszatiela”, w swojej antylegionowej powieści „Caritas”.

Prasa warszawska z uwagą śledziła dochodzące $z$ Wiednia sensacyjne wątki afery Redla, i korzystając z okazji, starła się im nadać znaczenie polityczne. „Gazeta Warszawska" w numerach 147-151 i 153 (od 1 do 7 czerwca) na s. 1 bądź 2 wyodrębniła osobny blok informacyjny, nadając mu tytuł Sprawa Redla. W ramach tego bloku, głównie za prasą wiedeńską, relacjonowano przebieg wydarzeń, których finałem było samobójstwo pułkownika oraz przebieg prowadzonego śledztwa. Niemało jest tu akcentów polskich. Na przykład w numerze 147 (1 czerwca) podano informację, że Redl, jako porucznik 80. lwowskiego pułku piechoty, był oficerem udzielają-

24 Pisały o tym także inne dzienniki: „Nowa Reforma” nr 248 (2 czerwca, numer popołudniowy) „Czas” nr 250 (3 czerwca, wyd. popołudniowe), „Gazeta Poranna 2 Grosze” nr154 (6 czerwca). Żydowską narodowość porucznika rezerwy Wilhelma Klauznera (bo o niego to chodziło) podkreślała „dwugroszówka”. 
cym się towarzysko i lubianym. Ta opinia odbiega od szeregu innych, które wypowiadali służący w innych pułkach Polacy, o czym donosiła prasa galicyjska. W numerze 148 ( 2 czerwca) podkreśla się, że sprzedaż przez Redla „najtajniejszych planów strategicznych" w wypadku wojny naraziłaby Austro-Węgry na „najcięższe niebezpieczeństwo". Punkt widzenia prasy polskiej na sprawę w tym wypadku jest literalnie zbieżny, co nie znaczy, że identyczne są intencje polityczne.

W tym samym numerze wskazuje się na występowanie Redla w roli rzeczoznawcy w procesach wytoczonych szpiegom w Krakowie i jego znajomości wśród oficerów garnizonowych w Krakowie, Lwowie i Przemyślu. Pisze się, że był on od czternastu lat na służbie szpiegowskiej „obcego państwa”25, ale bez ekscytacji właściwej części prasy galicyjskiej, to znaczy zasadniczo z pominięciem określeń moralnie dyskwalifikujących typu „niebywała” czy „haniebna” zdrada, choć i takie się zdarzaja (,zbrodnicza działalność”), bo zdrada jest zdrada. Afera dotykała mocno tych, którzy byli nią poruszeni, czyli adherentów Austro-Wegier, ale nie tych, którzy, jak endecka „Gazeta Warszawska”, stawiali na Rosję. W tym samym numerze pojawia się mocny akcent polityczny, mianowicie teza, że sprawa Redla (właśnie sprawa, a nie afera) „ma i dla nas niepoślednie znaczenie”:

Jest dziś publiczną tajemnicą, że akcja rządu austriackiego na polu popierania działań tzw. „komisji tymczasowej "odbywała się za pośrednictwem instytucji, w których zakresie działania był również pułkownik Redl. Jest przeto sprawą pierwszorzędnej wagi dla opinii polskiej dowiedzenie się czy i ewentualnie w jakim stopniu był czynny na tym polu szef biura kontr-szpiegowskiego p. pułkownik Redl (s. 2).

Za „Neues Wiener Journal” zacytowana jest opinia, że Redl kontaktował się z polskimi parlamentarzystami w Wiedniu, którzy naturalnie nic o jego działalności nie wiedzieli. Na razie wydaje się to oczywiste, ale nieco później dawało to pretekst do ich obwiniania przynajmniej o naiwność. W następnym numerze „Gazeta Warszawska” dementuje doniesienie „Neues Wiener Journal”, że Redl był Polakiem, podkreślając, jak cała prasa polska, że pochodził z rodziny „czysto niemieckiej”. Wzmiankuje, że podczas swojego pobytu w Warszawie Redl poznał pewną subretkę występującą w kabarecie „Aquarium”, z którą wyjechał do Wiednia.

W numerze 150 (4 czerwca) za „Ilustrowanym Kurierem Codziennym” podana jest opinia o roli Redla w zaszczuciu dyrektora policji krakowskiej, a za „Nowa Reformą" pogłoska w Krakowie o tym, że Redl wzorowo opracowywał szpiegowskie „elaboraty strategiczne”, zajmując się ponadto „gorliwie organizacjami politycznymi polskiej młodzieży w Galicji i stosunkiem tych, tak zwanych „wojskowych” organizacji do austro-węgierskiego ministerium wojny" (s. 2).

„Tak zwana” komisja tymczasowa, „tak zwane” wojskowe organizacje. Cudzysłowowa formuła użyta przez „Gazetę Warszawską” jest istotną oznaką dy-

\footnotetext{
${ }^{25}$ Prasa warszawska nie używała określeń typu „,szpieg rosyjski”, lecz stosowała eufemizmy w rodzaju: szpieg na służbie „obcego państwa”, „ościennego mocarstwa” lub nawet „zaprzyjaźnionego” mocarstwa.
} 
stansu i równocześnie wskazaniem przeciwnika politycznego, w dodatku w obciążającym kontekście afery szpiegowskiej. Można powiedzieć, że jej redakcja wykorzystała nadarzającą się okazję, by zaczernić obraz wroga i politycznie zagospodarować sensację. Świadczy też o tym błyskawiczne powołanie się w numerze 151 (5 czerwca) na „Gazetę Poranną Dwa Grosze” (tego samego dnia), która za enigmatycznym dobrze poinformowanym źródłem doniosła, że pułkownik był Żydem i swoje uprzednie nazwisko Redlich zmienił w 1902 roku na „typowo mieszczańskie niemieckie”: Redl (s. 2). W numerze 153 (7 czerwca) pojawia się informacja, że po odpowiedzi na interpelacje poselskie ministra Georgiego, głosami parlamentarzystów polskich i niemieckich odrzucono wniosek posła Nemoca o otwarciu dyskusji nad ta odpowiedzią (s. 2).

Wiele miejsca aferze szpiegowskiej poświęcił „Kurier Warszawski”, a pokaźny zasób informacji i komentarzy rozdysponowany został w postaci krótkich notek w rubrykach Ze świata i Telegramy Kuriera Warszawskiego albo odrębnych tekstów, często nawiązujących do wiadomości podawanych przez dzienniki galicyjskie („Czas”, „Gazeta Lwowska”, „Nowa Reforma”) oraz wiedeńskie i praskie. Zaznacza się trójdzielność pod względem sposobu przedstawiania afery, która najpierw - by odwołać się do typowych tytułów - naświetlana jest jako „sensacyjna sprawa szpiegowska”, następnie zaś „,sprawa Redla”, by w końcu przybrać postać pogłosową jako „echa sprawy Redla". Od końca maja przez kilkanaście dni w tym rytmie podawania informacji i jej komentowania redakcja starała się przykuć uwagę czytelnika.

W numerze 146 (29 maja) w dodatku porannym na s. 3 wybija się informacja podana za praską „Bohemią”, że uprawdopodabnia się pogłoska o szpiegostwie pułkownika Redla, pomimo oficjalnych zaprzeczeń, o czym ma świadczyć wizyta namiestnika ks. Thuna u komendanta korpusu w Pradze oraz szereg zarządzeń wojskowych. Następnego dnia w wydaniu głównym podano informację o samobójstwie i pogrzebie Redla oraz nawiązano do komunikatu ogłoszonego przez „Militärische Rundschau”. Podkreśla się, że afera wywołała w Wiedniu „niesłychaną sensację” i zrazu ten element wydaje się dominować w trybie informowania o niej. Do urzędowego organu armii austriackiej odwołuje się jeszcze tekst Sensacyjna sprawa szpiegowska, zamieszczony w numerze 148 (31 maja), na s. 3 dodatku porannego. W przeciwieństwie do wielu innych dzienników podana została precyzyjna informacja, że Redl był szefem biura wywiadowczego komendy korpusu w Pradze, czyli jednostki, która „służy podobnym celom, jak biuro ewidencyjne ministerium wojny”. Sprawa jest o tyle istotna, iż powszechnie przyjmowano, że pułkownik kierował biurem ewidencyjnym w Wiedniu. W konwencji sensacji przywołuje się informacje o homoseksualizmie Redla i jego wystawnym trybie życia.

W numerze 149 (1 czerwca) w wydaniu głównym na s. 12 opublikowany został obszerny tekst informacyjny pod takim samym tytułem jak w numerze porannym z poprzedniego dnia ${ }^{26}$. Podano szczegóły kariery Redla i opisano, jak doszło do uzyskania pewności przez władze wojskowe, że wysoko postawiony szpieg znajduje

${ }^{26}$ Bazował on na obszernej sekwencji informacji Niebywała afera szpiegowska w Austrii, wyeksponowanych na s. 1 wydania porannego „Nowej Reformy” (nr 245 z dnia 31 maja). 
się w dowództwie korpusu w Pradze. Podkreśla się, a właściwie przecenia, rolę pułkownika, jako jednostki paraliżującej (a nie mogącej sparaliżować) akcję militarną Austro-Węgier na Bałkanach.

$\mathrm{Z}$ rzeczy mogących zainteresować czytelnika podano informację o działalności w Wiedniu w jednym z mieszkań „,entralnego biura szpiegów” (nie można było dopowiedzieć, że rosyjskich, choć w następnym numerze mowa jest, iż kierowały nim Rosjanka i Dunka) i o uporczywie krążącej po Krakowie pogłosce o aresztowaniu kilkunastu osób wojskowych i cywilnych w związku ze sprawa Redla.

W numerze 150 (2 czerwca) w wydaniu głównym na s. 9-10 opublikowano obszerny tekst Sprawa Redla, który jest montażem informacji powtarzanych za „Neue Freie Presse”, praskimi „Narodnimi Listami” i wiedeńską „Zeit”. Mowa w nim, między innymi, o udziale Redla w „salwowaniu” szpiegów, jako skutku brania przezeń udziału w śledztwach i rzucaniu podejrzeń na niewinnych oficerów i osoby cywilne i o zdarzeniach, do jakich doszło w hotelu Klomsera w sobotę 24 maja. Podkreślono rolę szefa biura ewidencyjnego, pułkownika sztabu generalnego Augusta Urbańskiego w osaczeniu i udowodnieniu winy Redlowi. Identyczny tytuł nosi nota zamieszczona w numerze 151 ( 3 czerwca) w dodatku porannym na s. 2 i w wydaniu głównym na s. 7. Ponieważ w kilku pismach wiedeńskich, a zwłaszcza w „Neues Wiener Journal”, pojawiło się stwierdzenie, że Redl jest Polakiem, redakcja - podobnie jak wiele innych polskich dzienników, zadała kłam tej insynuacji, podkreślając czysto niemieckie pochodzenie Redla i jego „hakatystyczną nienawiść” do oficerów Polaków. Powraca wątek Rosjanki i Dunki, podpisujących się nazwiskiem Ujhelius. W numerze 152 (4 czerwca) w dodatku porannym na s. 3 podniesiono między innymi roztrząsaną w dziennikach praskich i wiedeńskich kwestię rozmiarów winy Redla. Te pierwsze wykazywały większe zdecydowanie w ocenie zasięgu zdrady, posuwając się nawet do hipotezy, iż Redl mógł wydać nawet „ordre de bataille” armii niemieckiej na wypadek wojny. Gazety wiedeńskie rozpisywały się natomiast na temat wydania przez Redla planów mobilizacyjnych armii austro-węgierskiej, co jeden z wysokich oficerów uważał z definicji za niemożliwe (pisała o tym „Zeit”), choć powszechnie mówi się o konieczności przebudowy twierdz jako skutku zdrady.

W numerze 152 (4 czerwca) w wydaniu głównym w rubryce Przeglad prasy wyodrębniono passus Po sprawie Redla, który jest obszernym streszczeniem artykułów zamieszczonych w „Czasie” i „Dzienniku Polskim”, komentujących kwestię fatalnych skutków dla bezpieczeństwa państwa zmuszenia do samobójstwa pułkownika Redla, fałszywego pojmowania honoru oficerskiego.

W kolejnych numerach „Kuriera Warszawskiego” z 5-7 i 9-10 czerwca doniesienia przybierają postać passusu w rubrykach informacyjnych, wyodrębnianych na ogół tytułem Echa sprawy Redla. Afera wyraźnie schodzi z pierwszego planu newsów, za to podawane są jej szczegóły; nawet odpowiedź na interpelacje poselskie ministra obrony krajowej Georgiego nie zostaje specjalnie podkreślona.

„Gazeta Poranna 2 Grosze", uchodząca jak byśmy dziś powiedzieli za endecki tabloid, wyróżniający się spośród dzienników warszawskich najbardziej zdecydowanym nastawieniem antysemickim, podawała informacje na temat afery w rubryce noszacej 
tytuł Różne nowiny oraz komentowała je w formie odrębnych artykułów, a nawet artykułów wstępnych (nie podpisanych nazwiskiem). W numerze 148 (31 maja) pisano o szczegółach samobójstwa Redla, do czego powrócono w numerze 151 (3 czerwca). Numer 152 (4 czerwca) otwiera na s. 1 artykuł wstępny noszący tyleż sugestywny, ile insynuujący tytuł Splatane nici. Tekst rozpoczyna się od przywołania powszechnie kursującej w obiegu prasowym wypowiedzi Franciszka Józefa o aferze Redla, jako najbardziej skandalicznym wydarzeniu mającym miejsce w czasie jego panowania. Jednakże jak gdyby dopowiada komentator, ta sensacja winna dawać do myślenia także Polakom, gdyż dotyczy ich „bezpośrednio”. Łączyć bowiem mają Redla „splątane nici” jego związków jako szefa austriackiego „biura ewidencyjnego” (Piłsudski dementował później tę powszechnie panującą mylną opinię) z „parlamentarzystami polskimi” w Wiedniu, biorącymi bezpośredni udział w „komisji tymczasowej” (konsekwentnie powtarzane cudzysłowy stanowią oznakę ironicznego stosunku do Koła polskiego i do politycznej platformy współpracy ruchu niepodległościowego). Redl miał z nimi pozostawać w bezpośrednich stosunkach, czego dowodem mają być twierdzenia pism niemieckich. Dziwny to sposób rozumienia dowodu, niekoniecznie prawdziwy, nawet wówczas gdyby podane zostało konkretne źródło prasowe, ale $\mathrm{i}$ tego nie ma.

W Warszawie miał Redl kontaktować się z niedookreślonym przez autora artykułu kręgiem osób, określanych mianem głupców, ludzi naiwnych i prowokatorów. Nie pada żadne nazwisko, ale piętnuje się ,pewien gatunek niepoczytalności politycznej”, który zagościł w Warszawie, a teraz został zdemaskowany wskutek afery szpiegowskiej. Ponadto Redl miał zwerbować Azefa, o czym pisała przed kilkoma miesiącami rosyjska gazeta „Łucz” (inne dzienniki powołujące się na te sensację jako źródło informacji podają prasę wiedeńska). Łatwo można było teraz utworzyć figurę, przemawiającą do odbiorcy jako odrażający fantazmat zdrady:

Zaprzedany ciałem i duszą Prusom Daszyński, niepoczytalny krzykacz Tetmajer, Śliwiński, który radykalnie wyleczył swe finanse, odkąd zajął się działalnością ,powstańczą”, Żydzi Diamand i Feldman, a na czele ich wszystkich - szpieg i zdrajca Redl, z nim może Azef - oto czynniki, które na gruncie polskim miały realizować „orientację austriacką” i uszczę́liwić dzielnicę naszą powstaniem na rzecz Austrii.

Opatrzność, dopowiada komentator, uchroniła przed hańbą, jako byłoby przelanie „krwi polskiej za złoto pobrane przez szpiegów austriackich”. Uczucie wstydu winno ogarnąć tych, którzy dali się uwieść, choć na chwilę „orientacji austriackiej”.

W tym samym numerze w rubryce Różne nowiny w kontekście sprawy kontaktów pułkownika w Wiedniu z damami trudniącymi się rzemiosłem szpiegowskim, posługującymi się nazwiskiem Ujheljus pojawia się kategoryczne stwierdzenie, które staje się politycznym punktem oskarżenia ruchu strzeleckiego, powtórzonego za „Gazetą Poranną 2 Grosze" przez Zygmunta Balickiego (o czym będzie jeszcze mowa):

Z papierów zabranych w mieszkaniu Redla i z jego przedśmiertelnego zeznania na piśmie wynika, iż był on faktycznym, chociaż ukrytym, organizatorem stowarzyszeń strzeleckich w Galicji, formowa- 
nych z takim pośpiechem podczas naprężenia się stosunków politycznych z powodu kryzysu bałkańskiego. Oczywiście, iż jednocześnie wysyłał wyczerpujące raporty o tych organizacjach stronie zainteresowanej. Wynikiem tej działalności była interwencja dyplomatyczna w Wiedniu ${ }^{27}$.

Teza sformułowana została kategorycznie, ale zbudowano ją na przesłankach fałszywie wskazujących źródła informacji. Nie wiadomo, skąd redakcja mogła wiedzieć (byłaby taką jedyną na świecie), że we wzmiankowanych dokumentach czy zeznaniu, są jakiekolwiek treści odnoszące się do roli Redla jako organizatora ruchu strzeleckiego.

W następnym numerze pisma opublikowano odrębny tekst Redl Żydem, w którym „zdemaskowano” Redla jako Żyda, który swoje nazwisko Redlich i wyznanie zmienił w 1902 roku. Podkreślono w nim, że we Francji szpiegiem jest z reguły oficer Żyd (pomijając kompletnym milczeniem dzieje afery Dreyfusa), podobnie w Rosji i, jak się teraz okazało, w Austrii. „Żydowskie pochodzenie Redla” - podkreśla dziennikarz - „wyświetla wiele rzeczy”, a w szczególności „poufne stosunki” Redla z „osławioną” Komisją Tymczasową (w której ważną rolę odgrywają „Diamanty i Feldmany”) i jego kierownictwo „w organizowaniu pseudowojskowych stowarzyszeń strzeleckich". Konkluzja jest następująca:

Żyd, wysoki oficer austriacki, jednocześnie szpieg i zdrajca oraz Żydzi, socjaliści galicyjscy podali sobie bratnie dłonie, by wywołać ruch, który pogrążył by nas w przepaść prawie bez wyjścia ${ }^{28}$.

W artykule wstępnym Mistrze zdrady, opublikowanym w numerze 154 (6 czerwca) na s. 1, na kanwie afery Redla i jego rzekomo żydowskiego pochodzenia, budowane jest przesłanie, stanowiące dobitny wyraz ideologicznego antysemityzmu, którego późniejszym odpowiednikiem jest pojęcie żydokomuny. Redl czy raczej Redlich włączony zostaje do galerii „demonicznych zdrajców pochodzenia żydowskiego”, będącej znakiem obecnych czasów. Padają nazwiska Azefa, Bakaja i Hartinga, właśnie owych mistrzów zdrady, pracujących na dwa fronty. Matecznikiem zdrady ma być żydowskie poczucie obcości, nienawiść i pogarda dla chrześciajn. Nie przynależący duchowo do wspólnoty danego narodu Żyd - utrzymuje dziennikarz - z natury będzie skłonny do zdrady, i nie odczuje on z tego powodu żadnych wyrzutów sumienia. Bo będzie nim kierować resentyment do obcych. Łatwo też im o kamuflaż, gdyż w ich psychice nie nastąpią załamania i przejścia duchowe, jakie byłyby udziałem reprezentantów krwi i instynktów narodów europejskich.

Przychodziło im to łatwo, bo zarówno pod mundurem sztabowca austriackiego, jak pod kurtką rewolucjonisty rosyjskiego, tu i tam biło serce Żyda, pełne nienawiści i pogardy dla „gojów”, których jeden wysyłał na szubienice lub pod bomby, drugi zamierzał wysłać setkami tysięcy na pola przegranych bitew.

\footnotetext{
27 „Gazeta Poranna 2 Grosze” 1913, nr 152 (4 czerwca), s. 1-2.

28 „Gazeta Poranna 2 Grosze” 1913, nr 153 (5 czerwca), s. 2.
} 
Zarówno ten artykuł, jak i poprzednio wskazywane, stały się podstawą politycznego wystapienia Zygmunta Balickiego, z którym w ostrą polemikę wszedł Józef Piłsudski. W ten sposób dwóch wybitnych adwersarzy politycznych, reprezentujących wrogie sobie ideologie, starło się na gruncie afery Redla.

Radykalne opinie „Gazety Porannej 2 Grosze” nawet część prasy warszawskiej odbierała jako insynuacje (o czym będzie jeszcze mowa), ale szereg liczących się tytułów podzielających racje Narodowej Demokracji bądź je respektujących („Gazeta Warszawska”, „Kurier Warszawski”) niekoniecznie skłonny był rezonować rewelacjami gazety o której mowa. Były też dzienniki reprezentujące inną opcję polityczną, które bez reszty aprobowały wykładnię polityczną afery Redla w wydaniu „,dwugroszówki”. Przykładem jest konserwatywne „Słowo”, które w obszernym streszczeniu tekstów zamieszczonych w „Gazecie Porannej 2 Grosze”, całkowicie solidaryzowało się z ich wymową polityczną ${ }^{29}$. „Słowo” zresztą niespecjalnie interesowało się głośną aferą, choć zamieszczało dość oderwane od siebie wzmianki, na przykład o dokonanym przez policję wiedeńską spisie poddanych rosyjskich i o pogłosce, że skazanie przed kilku laty w Petersburgu za szpiegostwo korespondenta austriackiego Biura Korespondencyjnego barona Ungerna Sternberga było efektem działalności Redla, który w ten sposób go się pozbył.

Nowopowstały „Kurier Ilustrowany”, będący jak gdyby warszawskim wariantem „Ilustrowanego Kuriera Codziennego”, nie poświęcił aferze szpiegowskiej zbyt wiele miejsca, choć w odrębnym tekście Sprawa szpiegostwa Redla, przywołał wiele jej elementów , zwłaszcza koncentrujących się szczegółach wydarzeń i przebiegu śledztwa ${ }^{30}$. Podano dokładną lokalizację hotelu Klomsera. Zwraca uwagę nie wiadomo skąd zaczerpnięta opinia, że śledztwo nie potwierdziło „pogłoski o homoseksualnych zboczeniach Redla". Na stronie tytułowej numeru 156 z dnia 7 czerwca wyeksponowano niewielki objętościowo tekst $A l f r e d ~ R e d l$, jednakże ilustrowany fotografią pułkownika. Mowa nim między innymi o nie satysfakcjonującym opinię publiczną wystapieniu ministra Georgiego i o jej negatywnym nastawieniu do „samosądu oficerskiego", jakim było wymuszenia samobójstwa na pułkowniku.

Afera Redla stała się przedmiotem zainteresowania tygodników warszawskich. Najpoważniejszy nad Wisłą i miarodajny „Tygodnik Ilustrowany” poświęcił jej osobny całostronicowy esej ${ }^{31}$, choć zazwyczaj starannie unikał poruszania sensacyjnej tematyki, czyniąc niekiedy w tej kwestii znaczące wyjątki, jak w poruszającej opinię

${ }^{29}$ Warszawskie echa sprawy Redlowskiej”. „Słowo” 1913, nr 150 (7 czerwca), s. 3. Taki sam tytuł nosi passus zamieszczony w rubryce $Z$ różnych stron, prowadzonej w „Dzienniku Poznańskim” (nr 130 z 10 czerwca, s. 3). Powołano się w nim aprobatywnie na opinie „Słowa” i „Gazety Porannej 2 Grosze”. „Dziennik Poznański” w artykule „Strzelcy” w Galicji, podpisanym pseudonimem Niejeden (nr 133 z 13 czerwca, s. 1) z zadowoleniem odnotował rozporządzenie ministerstwa obrony krajowej AustroWegier o „ograniczeniu działalności związków strzeleckich”. Ostudzone zostały zapały „entuzjastów” i zwolenników „rządów narodowych”, a poza tym swoje zrobiły doświadczenia roku 1863, które „na szczęście - cieszy się komentator - nie przeszły bez następstw i trwałych śladów”.

30 „Kurier Ilustrowany” 1913, nr 151 (2 czerwca), s. 3.

31 Szpieg, „Tygodnik Ilustrowany” 1913, nr 24 (maja), s. 468. Tekst podpisany kryptonimem Dees [być może kryje się pod nim nazwisko Stanisława Dzikowskiego]. 
publiczną głośnej sprawie Damazego Macocha, zbrodniarza z Jasnej Góry. Jego autor odniósł się przede wszystkim do zjawiska współczesnego szpiegostwa, które w stosunku do niedawnej epoki uległo zmianom, choć zawsze wszystkie armie i służby dyplomatyczne korzystały z usług służb wywiadowczych. Dawniejszy „romantyzm szpiegowski” obecnie odszedł w przeszłość, a usługi wywiadowcze stały się rzemiosłem, niekiedy źle wynagradzanym, w którym nawet uczucie nienawiści nie odgrywa żadnej roli. To rzec można zimny fach uprawiany wyłącznie za pieniądze przez tajnych agentów, gotowych posunąć się do każdej nikczemności, z prowokacją i fabrykowaniem dokumentów włącznie. $Z$ tego właśnie powodu są oni niebezpieczni nawet dla własnych mocodawców.

Najwyższą kategorią szpiega jest oficer sztabu generalnego pozyskany dla wrogiej armii, za którego usługi żadna cena nie jest wygórowana. Szpiegiem tej klasy okazał się pułkownik Redl, którego afera, co podkreśla się, „należy do najbardziej rozgłośnych wydarzeń z doby współczesnej”, i to w krytycznym momencie „ostatniego przesilenia wojennego pomiędzy Austrią a Rosją":

Rozkwit działalności szpiegowskiej pułkownika Redla przypada właśnie na tę epokę, którą nie tak dawno cały świat przeżywał z drżeniem serca, kiedy widmo wojny wisiało tuż nad głowami.

Po tej konstatacji autor tekstu cytuje obszerny fragment komentarza jednego z publicystów wiedeńskich, który opisuje paradoks informacyjny, jakim była blokada informacyjna w Austro-Węgrzech na temat sytuacji „naszych dzielnych żołnierzy” podczas wojny na Bałkanach, a z drugiej strony wskutek działalności Redla całkowita na ten temat wiedza przeciwnika. Komentator mówi o „wielkim tryumfie szpiegostwa”, tym bardziej, że jak dodaje autor, pułkownik kierował biurem ,przeciw-szpiegowskim". To stanowisko umożliwiało mu kontaktowanie się z najbardziej nawet podejrzanymi agentami, konfidentami oraz obcymi konsulami i oficerami. W zachowaniach służbowych pułkownika nic nie wzbudzało podejrzeń, za to winny zwracać uwagę jego ,instynkty dzikie i nieposkromione, kult dla rozrzutności i wszystkie wyrafinowane obrzędy żądzy". Ale wysocy oficerowie c. k. armii, stwierdza autor tekstu, nie byli psychologami, i nawet „fenomenalna” rozrzutność Redla, zamiast mu szkodzić, raczej pomagała w karierze.

W tym eseju o szpiegostwie i austriackim superszpiegu, z zamieszczonym jego zdjęciem nie ma bezpośrednich odniesień do spraw polskich. Widać, że jego autor unika kontekstów politycznych, starając się postawić diagnozę zjawisku, zdającemu się być właściwością czasów obecnych, w których, jak powiada, „,wszyscy szpiegują wszystkich i nikt się temu nie dziwi”. W ten sposób nobliwy i ukazujący się od blisko półwiecza „Tygodnik Ilustrowany” starał się stwarzać sugestię apolityczności, co nie było takie łatwe w dobie wojny na Bałkanach. Przy tym poruszał obchodzących wszystkich sprawę w sposób mogący wzbudzić zainteresowanie nie tylko u czytelnika żądnego sensacji.

Do kategorii eseju na temat szpiegostwa zaliczyć można artykuł wstępny Wacława Masłowskiego ,,Afera ” pułkownika Redla, zamieszczony w konserwatywnej „Kronice 
Powszechnej" ${ }^{32}$. Ten lwowski tygodnik często uciekał się do topiki lamentacyjnej, opisując moralny upadek cywilizacji współczesnej. I tak jest w wypadku wzmiankowanego artykułu, w którym zjawisko szpiegostwa zinterpretowane zostało jako znak czasu. Dawniej - argumentuje autor - wojny rozgrywano na poziomie taktyki, a obecnie przenosi się ją na poziom strategii, czyli w istocie operacyjnego przygotowania się do niej, dlatego też w sztabach wojskowych na znaczeniu zyskują departamenty wywiadowcze. Wszystko jest dokładnie zaplanowane, ale nawet najdokładniejszą maszynerię przygotowań, niesłychanie kosztowną może uczynić nieużyteczną usytuowany wysoko w hierarchii sztabowej szpieg. Tak stało się w wypadku Redla, którego do zdrady popchnęła niepohamowana chciwość, materialistyczna żądza użycia, hedonizm, nazwane przez autora „chorobą naszych czasów”. Autor rozważa moralne aspekty szpiegostwa, przystając na obiegową opinię, że w razie wybuchu wojny zdrada Redla mogłaby spowodować klęskę armii austriackiej. W zakończeniu jednak „ustawiczna chwiejność” tej armii, o której mówiło się w zimie, znajduje teraz wytłumaczenie, jako konieczność manewrowa. Wywiad austriacki wiedział już, że plany mobilizacyjne zostały sprzedane „obcemu mocarstwu”.

Niewielkie artykuły wraz ze zdjęciem Redla pojawiły się też w innych tygodnikach warszawskich. „Świat” zamieścił artykuł pod takim samym tytułem, jak w „Tygodniku Ilustrowanym”, również z fotografią Redla ${ }^{33}$. Ale jest on mniej interesujący, głównie z powodu swojej lakoniczności. Akcent położony został na szkody materialne działalności Redla, biorące się choćby z koniecznością przebudowy twierdz i fortyfikacji armii austro-węgierskiej. W tym samym numerze mowa jest o głośnych wydarzeniach $\mathrm{w}$ budapeszteńskim parlamencie, nawet $\mathrm{z}$ sugestywnym rysunkiem, ale nie łączy się ich z aferą Redla, jak to się tu i ówdzie zdarza, pod figurą moralnej kompromitacji czy nadwerężenia powagi Austro-Węgier. I w tym wypadku widać niechęć do zajęcia stanowiska politycznego, choć w jednym z numerów opisany został wzmożony „ruch narodowy wśród ludności polskiej” na Spiszu i Orawie ${ }^{34}$, z antymadziarskim akcentem. Redakcja nie wykorzystała również otoczki sensacji towarzyszącej aferze, widocznie, zostawiła to swoim czytelnikom, którzy równocześnie bywali niekiedy czytelnikami „Gazety Warszawskiej”, „Kuriera Warszawskiego” czy „Słowa”.

„Złoty Róg”, istniejący na rynku prasowym od 1911 roku, zamieścił niewielki objętościowo tekst poświęcony „smutnej pamięci bohaterowi wszecheuropejskiej afery szpiegowskiej"35. Przewija się w nim kilka obiegowych opinii, dotyczących motywów, które popchnęły Redla do zdrady (rozrzutność, hulaszczy tryb życia, rozpusta), strat materialnych, jakie poniesie armia austro-węgierska z powodu konieczności jej reorganizacji i zmiany planów mobilizacyjnych czy wymuszonego samobójstwa

\footnotetext{
32 „Kronika Powszechna” 1913, nr 23 (7 czerwca), s. s. 375- 378.

33 Szpieg [tekst nie podpisany], ,Świat” 1913, nr 24 (14 czerwca), s. 33.

34 Jast. [kryptonim], Sprawa polska na Węgrzech”, „Świat” 1913, nr 25 (21 czerwca), s.7.

35 Pułkownik Redl [nie podpisany], „Złoty Róg” 1913, nr 24 (15 czerwca), s. 9. Na tejże stronie fotografia Redla.
} 
pułkownika. Akcent paradoksu wnosi natomiast powtórzony za prasą francuską komentarz, że Redl uratował pokój europejski, gdyż na podstawie jego doniesień szpiegowskich państwa trójporozumienia mogły nabrać pewności o zdecydowanej woli współdziałania Niemiec i Austro-Węgier w wypadku wybuchu wojny. To mogło od tej wojny odstręczać. W tym samym numerze podano też informację o dymisji królewsko-cesarskiego komisarza w Chorwacji, "gnębiciela i ciemięzcy" Cuvaja.

Wydawany w Warszawie tygodnik ,Zorza”, adresowany do odbiorcy ludowego, informował o aferze Redla w rubrykach Najświeższe wiadomości (nr 23 z 5 czerwca) i Przeglad polityczny ( $\mathrm{nr} 24$ z 12 czerwca i $\mathrm{nr} 30$ z 24 lipca). Podnoszono w nich obiegowe w prasie watki, dotyczące na przykład „najhaniebniejszej rozpusty” pułkownika, który, by zaspokoić na nią środki, uciekł się do zdrady czy okoliczności jego samobójstwa. Wyrażono też powszechnie kursującą opinię, że gdyby podczas „ostatniej mobilizacji” Austro-Węgry uwikłałyby się w wojnę, poniosłyby z powodu zdrady „klęskę straszną”. Periodyk ten o tyle warty jest wzmianki, że w rubryce Przegladu politycznego wprawdzie lakonicznie, ale ciagle informował o aferach szpiegowskich w Europie. W lipcu i sierpniu odnotowano kilka takich spraw, które wskazywały podtytuły rubryki: Wynalazca szpieg (o kapitanie armii rumuńskiej, który dopuścił się zdrady, aby pozyskać środki na udoskonalenie modelu samolotu), Szpiegostwo wojskowe w Austrii (zataczający się krąg oskarżeń wobec ,pomocników” Redla), Szpiegostwo we Włoszech (aresztowanie hr. Morozzo, wysokiego urzędnika w ministerstwie wojny z zarzutem kierowania szajką szpiegowska), Ujęcie szpiega (proces w Wilnie pisarza wojskowego Kisielewa oskarżonego o wydanie planów mobilizacyjnych Rosji Niemcom), Aresztowanie szpiegów (w Krakowie zatrzymano dziewięciu studentów pod zarzutem szpiegostwa „na rzecz jednego z sąsiednich państw"), Szpiegostwo w armii pruskiej (na placu ćwiczeń w obecności podwładnych aresztowano pułkownika Steina, kierującego „związkiem szpiegowskim”). Najciekawsza jest jednak informacja podana w numerze $27 \mathrm{z}$ dnia 3 lipca na s. 424, w której jest mowa o surowym ukaraniu przez sąd wojskowy w Przemyślu dragonów czeskich za to, że „wznosili okrzyki na cześć Rosji”. Dwóch dragonów skazano na 8 i pół roku więzienia, a dziewiętnastu na od 4 do 7 lat więzienia. Żaden inny fakt (poza wzmiankowaną epidemią we Lwowie samooskarżeń o współpracę z Redlem) nie mówi lepiej o skutkach psychozy powstałej w warunkach maniakalnego podejrzewania o działanie na szkodę Austro-Węgier, w tym wypadku żołnierzy, w końcu jawnie wznoszących okrzyki, będące zresztą wyrazem przekonań wielu, jeśli nie większości Czechów. Naturalnie, była to niesubordynacja, polegająca na manifestowaniu przyjaznych uczuć do ościennego mocarstwa, ale kara za nią miała w sobie coś, co kojarzy się z pewnymi sytuacjami w Przygodach dzielnego wojaka Szwejka. Inna sprawa, że psychoza szpiegowska szerzy się w Europie, może z wyjątkiem wyspiarzy, chyba najlepiej chroniących swoje tajemnice wojskowe. A może Anglicy byli tylko najbardziej dyskretni?

Polityczne wątki afery Redla rozegrała w bezpardonowy sposób „Myśl Niepodległa". Periodyk ten, redagowany $\mathrm{i} w$ istocie autorsko zdominowany przez Andrzeja Niemojewskiego, był organem wolnomyślicielskim i antyklerykalnym, 
ukazującym się trzy razy w miesiącu. Ale nie tylko ateizm i kwestie światopoglądowe były przedmiotem zainteresowań redaktora, gdyż organ ten miał zdecydowane nastawienie polityczne. „Myśl Niepodległa” wręcz dogmatycznie zwalczała orientację austriacką, by już wkrótce w czasie wojny stać się rozsadnikiem racji skrajnie rusofilskich. Nie mogła nie zaatakować listu biskupów galicyjskich ${ }^{36}$, przy okazji ironizując na temat „dyplomacji bałkańskiej” Austro-Węgier, prowokującej wśród Polaków „nieziszczalne rojenia”, w rzeczywistości zaś doprowadzającej Galicję do „niebywałego przesilenia gospodarczo-finansowego". W tym samym numerze w artykule zatytułowanym Redl gwałtownie zaatakowana została „orientacja redlowska”, którą to nazwę utożsamiono wprost z polityką stawiania na Austro-Węgry.

Jeżeli rak zdrady toczy tak potężne organizmy, jak wielkie mocarstwa, to cóż dopiero mówić o narodzie, takim, jak nasz! (s. 796).

$\mathrm{W}$ istocie to formuła niewiary narodowej, wyprowadzona w schemacie nazbyt prostego sylogizmu. Za jej pomocą pogrążać można było wszelkie przejawy aktywizmu, w czym właśnie „Myśl Niepodległa” celowała, jakby wbrew przymiotnikowi w nagłówku pisma. W numerze, o którym mowa w kontekście afery Redla, pojawia się inny jeszcze artykuł, którego tytuł doskonale oddaje myślenie życzeniowe jego autora: Likwidacja zabawy wojennej w Galicji. Jego sens sprowadza się do opinii, że dobiega końca szkodliwa maskarada strzelecka szaleńców wierzących w militarny sojusz z Austro-Węgrami.

W ukazującym się w Warszawie miesięczniku społecznym i literacko-naukowym „Prąd” afera Redla znalazła swój komentarz polityczny w stałej rubryce tego pisma $Z$ miesiaca ${ }^{37}$. Komentarz napisany został pod figura fictio legis, czyli z założeniem hipotetycznego stanu rzeczy, co by stało się z Galicją gdyby doszło do wojny Austro-Węgier z Rosją. Wskutek zdrady Redla „mocarstwo ościenne”, czyli Rosja, doskonale poinformowana o planach dyslokacyjnych i wyposażeniu c. k. armii, na pewno odniosłaby nad nią zwycięstwo. A byłby to fakt „brzemienny w następstwa złowrogie i nieobliczalnej wagi dla naszego narodowego bytu". Rozprawiono by się z Galicją za „formowanie drużyn strzeleckich”, autonomia zostałaby zaprzepaszczona, w Uniwersytecie Jagiellońskim prowadzono by wykłady w języku „nieco odmiennym" od polskiego. Strach pomyśleć - powiada komentator - że nad urzeczywistnieniem tej hipotetycznej fatalności pracował Komitet Tymczasowy (chodzi o Komisje Tymczasowa), którego związki z Redlem zostały stwierdzone. Przy okazji skrytykowane zostało wystapienie prezesa Koła polskiego w Wiedniu, który miał ,skompromitować się haniebnie" deklaracją lojalizmu względem Austro-Węgier, nieprzyzwoitą i uzurpującą sobie prawo występowania w imieniu narodu polskiego. Nie wspomniał

${ }^{36}$ W artykule wstępnym Manifest episkopatu galicyjskiego, „Myśl Narodowa” 1913, nr 245 (czerwiec, dekada druga).

37 „Prąd” 1913, nr 6 (czerwiec), s. 168.Autorem komentarza jest P[aweł] O[bszyc]. 
natomiast o braku lojalności rządu względem Polaków, co ma się wyrażać, między innymi, uprzywilejowaniem Rusinów.

$\mathrm{Z}$ afery Redla prześmiewcze treści dobywała prasa humorystyczna. W warszawskim tygodniku „Mucha” opublikowany został wiersz Skandal dziejowy, opisujący 11-zgłoskowcem historię hulaszczego życia, zdrady i śmierci pułkownika Redla ${ }^{38}$. „Utwór” jest najzupełniej banalny i nie warto by o nim wspominać, gdyby nie jego wymowa polityczna, uwierająca czujną cenzurę w Krakowie (władze austriackie nie miały wpływu na druk tekstów ukazujących się w Królestwie, ale mogły zabraniać ich rozpowszechniania na terenie C. K. Monarchii). W rubryce Wyroków prasowych prowadzonej w urzędowej „Gazecie Lwowskiej” pojawia się zakaz „rozszerzania” (rozpowszechniania) pierwszej i ostatniej zwrotki wiersza o którym mowa, gdyż te „Zawierają w całej swej osnowie znamiona zbrodni" ${ }^{39}$. To formuła prawna, obok której stosowano łagodniejszą, mówiącą o „znamionach występku”40. Wyglądające na groźne paragrafy nie skutkowały jednak odpowiednio brzemiennymi w skutki postępowaniami sądowymi wobec pism galicyjskich czy zakazami kolportażu w Galicji dzienników i periodyków wydawanych w Królestwie ${ }^{41}$. Machina sądownicza po prostu demonstrowała swoją czujność. Warto przytoczyć początkową i końcową zwrotkę Skandalu dziejowego, noszących „znamiona zbrodni” z tego powodu, że aferę Redla potraktowano w nich jako symptom upadku politycznego Austro-Węgier:

\footnotetext{
W Austrii, w której niepokój trwa stale,

Zdarzył się dzisiaj skandal nad skandale;

Skandal szatański, z samych piekieł flanca,

Co wieńczy smutne panowanie Franca.

W wielkim popłochu komendy i sztaby,

Na tronie zatrząsł się Franz-Joseph słaby,

A sąsiad szepcze: „Więcej takich Redli,

A wkrótce, Austrio, będziem ciebie jedli”.
}

W tym samym numerze pewien wątpliwy dowcip również został potraktowany, jako inkryminowany. Natomiast w numerze 14 „Muchy” z 14 czerwca pojawiają się dwa 8-zgłoskowe wiersze nawiązujące do głośnej afery: Odpowiedź pismom wiedeńskim (s. 5) i Pan Redl (Ballada wiedeńska) (s. 8). Pierwszy daje odpór prasie wiedeń-

38 „Mucha” 1913, nr 13 (6 czerwca), s. 3.

$39 \mathrm{~W}$ numerze 134 z 14 czerwca.

$40 \mathrm{Z}$ taką kwalifikacją i odpowiednio zakazem ,rozszerzania” spotkał się artykuł Po śmierci pułkownika Redla, opublikowany w „Głosie” i „Naprzodzie” w numerach 124 z 3 czerwca 1913 roku.

${ }^{41}$ W którym, inaczej niż w Galicji, na wydawców za nieprawomyślne treści nakładano dotkliwe kary pieniężne lub karano wyrokami twierdzy, co spotkało na przykład Wiktora Gomulickiego. W c. k. Monarchii zdarzały się nawet przypadki wycofywania konfiskaty, a więc przyznania się cenzury do błędu. Przykładem jest ta oto notka z „Nowej Reformy” 1913, nr 249 (poranny) z 3 czerwca, s. 1: „Charakterystycznym jest zniesienie konfiskaty „Prager Tagblattu”, a mianowicie jednego numeru tego dziennika, za doniesienie o aferze Redla. Zniesienie konfiskaty uzasadniono tym, że wiadomość podana przez dziennik okazała się tymczasem prawdziwa”. 
skiej, utrzymującej że Redl był Polakiem. Ów odpór zasadza się na ironicznym koncepcie, że tak wyrafinowanym szpiegiem nie mógł być Polak, reprezentujący „niższą rasę”, lecz Szwab, „człowiek pierwszej klasy”. Drugi wiersz jest natomiast trawestacją ballady Mickiewicza Pani Twardowska. Oto podczas hulanki czart wyskakuje z kielicha, $\mathrm{i}$ :

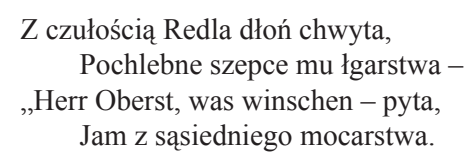

W ostatniej zwrotce zaprzedany diabłu Redl dostrzega na dnie kielicha postronek. „Mucha” odnotowała też w formie wiersza dymisje „bana-tyrana” Cuvaja, natrząsała się z namiestnika Korytowskiego, jako „c. k. murzyna” i „lwowskiego agenta Habsburgów”, kpiła z agresywnych zachowań wobec siebie na Bałkanach „braci” Słowian.

Afera Redla stała się najważniejszym elementem frontalnego ataku na Komisję Tymczasową i ruch strzelecki przeprowadzonego przez Zygmunta Balickiego, jednego z czołowych liderów Narodowej Demokracji i redaktora naczelnego ukazującego się w Warszawie „Przeglądu Narodowego”. Na łamach tego miesięcznika w numerach 5 (maj) i 6 (czerwiec) z 1913 roku opublikował on dwuczęściowy obszerny artykuł o wymownym tytule „Dezorientacja” austriacka, który można uznać za zdecydowany wykład racji endeckich, demaskujących nastroje wojenne w Galicji, jako dzieło prowokacji politycznej. Autor wychodzi od niedawnego zarządzenia wydanego przez czynniki rządowe w Austrii, które z powodu osłabnięcia napięcia pomiędzy C. K. Monarchią a Rosją, sprowadziło ,armię polską" ${ }^{42}$ do roli stowarzyszenia sportowego. Stan ,ustawicznego nerwowego podniecenia i oszałamiającego pogotowia wojennego" przeminął, a w jego miejsce wszedł nastrój depresji i rozczarowania.

Wypadki dały surową lekcję błędów popełnionych przez orientację austriacką i prowadzoną przez nią politykę powstańczą. Odwage przyznania się do łatwowiernego zawierzenia dobrej woli Wiednia wykazał, według publicysty, tylko poseł Włodzimierz Tetmajer, który publicznie wyznał, że Austria „wyzyskuje naszą uczciwość i uczucie w sposób najcyniczniejszy i z najwstrętniejszą hipokryzją i fałszem świętoszka egoisty” (nr 5, s. 452). W podobnym duchu wypowiadał się „Kurier Lwowski”, a przywołany zeń cytat odnosi się do przykładów zaczerpniętych z historii notorycznego wykorzystywania nastawien zbrojnych Polaków przez Austrię. Balicki, respektując tę zmianę stanowiska, powstałą jako skutek zawodu sprawionego przez „naturalnego sprzymierzeńca” (ironiczny cudzysłów), nie obwinia jednak polityki austriackiej. Przeciwnie, jest ona z punktu widzenia politycznego i prawnego

42 Cudzysłowów jest wiele w tym artykule, i stanowią one ironiczną oznakę dystansu do objętego nim wyrażenia. W pasji polemicznej liczy się też karykaturowanie pojęć (,dezorientacja”) oraz stosowanie określeń prześmiewczych typu „parodia” (ruchu powstańczego). Ponadto wysoce funkcjonalna jest opozycja trzeźwość - gorączka, oszołomienie, nerwowość, podniecenie, łatwowierność. 
Wiednia „W zupełnym porządku”. Przecież Austria niczego nie obiecywała, to polityczna część Galicji sama z siebie wytworzyła iluzję mitycznego poparcia i sama zapędziła się w irracjonalne przygotowywanie się do wojny. Polaków nawet nie łudzono widokiem korzyści narodowych, a podsycany czy raczej samopodsycający się wśród nich nastrój powstańczy był potrzebny Austrii, gdyż zastępował on akcję polityczną.

Według Balickiego, orientacja austriacka zupełnie nie zrozumiała „doniosłości dla naszego narodu wojny bałkańskiej”, i siły Słowian południowych, wpływających na stosunki narodowościowe w c. k. Monarchii. Nie wykorzystano politycznie możliwości nacisku polskiego na Wiedeń, co więcej pośrednio optowano na rzecz Berlina, który nie mógł pozwolić na zesłowiańszczenie się Austrii. Szkodzono Rosji i wspomagano Austrię, argumentuje publicysta - w obu wypadkach z uszczerbkiem interesu polskiego, nadwerężanego też przez politykę Wiednia i Berlina wobec Rusinów. Balicki obwinia Komisję Tymczasową o „bezczelne” wykorzystywanie patriotyzmu młodzieży polskiej, co stawia ten organ na płaszczyźnie odpowiedzialności nie tylko politycznej i moralnej, ale ,wprost kryminalnej” wobec narodu. Wykolejona młodzież tworzyć będzie, ironizuje publicysta, kombatancki zastęp „,byłych uczestników niedoszłego powstania”. Z drugiej jednak strony zauważa, iż z całej tej „dezorientacji" austriackiej pozostanie jeden wartościowy element, o ile będzie skanalizowany w duchu wychowania narodowego, a mianowicie, upowszechniające się w całej Europie idee militaryzmu, idące w kierunku pracy nad młodym pokoleniem. A więc nie powstaniec, konspirator i rewolucjonista, ale żołnierz wychowany w duchu patriotycznym i obywatelskim jest tu ideałem wychowawczym.

Część II ,Dezorientacji” austriackiej ufundowana jest na podłożu afery Redla, określanej mianem , jedynego w swoim rodzaju skandalu w życiu wojskowości europejskiej”. Balicki krytykuje prasę polską za koncentrowanie się na stronie „epizodyczno-anegdotycznej” tej afery, i przemilczenie roli Redla „w kryzysie wojennym galicyjskim i wpływie jego na stosunki specjalnie polskie" (nr 6, s. 562). Nie do końca jest to prawda, ale istotnie, przemilczenia i niedopowiedzenia dzienników i periodyków reprezentujących orientację austriacką dawały się zauważyć. Balicki, jako pozytywny przykład zainteresowania się politycznymi aspektami afery Redla podaje artykuły zamieszczone w „Gazecie Porannej 2 Grosze” i na „faktach” w niej podanych (do wszystkich odnosi się bezkrytycznie) buduje swój wywód polityczny, który jest jednym wielkim oskarżeniem ruchu niepodległościowego o to, iż stał się on ofiarą prowokacji, co nie znaczy, że nie było w nim cynicznych agentów zdających sobie sprawę, kim są ich mocodawcy i jaki jest skryty cel ich zakulisowych działań.

Największym zagrożeniem byłoby narzucenie narodowi polskiemu akcji zbrojnej na drodze prowokacji, i omal do tego nie doszło. Redl utrzymywał ożywione stosunki z ,wiecznymi powstańcami” polskimi, których ostatnią mutacją byli rewolucjoniści z Królestwa, teraz organizujący ruch niepodległościowy w Galicji. Miał on kontakty z Komisją Tymczasową; do spotkań dochodziło w Wiedniu i w Krakowie. Poznał niektórych członków Koła polskiego. Balicki bezkrytycznie powtarza za „dwugroszówką", że z dokumentów znalezionych w mieszkaniu Redla w Pradze i z jego zeznań napisanych przed popełnieniem samobójstwa wynika, że „był on faktycznym, choć 
ukrytym organizatorem związków i drużyn strzeleckich w Galicji” (nr 6, s. 564). Przy tym pracował na rzecz obu mocarstw, gdyż informacje o ruchu strzeleckim przekazywał służbowo sztabowi generalnemu, a jako szpieg władzom rosyjskim, które wskutek powzięcia pewnych wiadomości interweniowały nawet w Wiedniu. Austriacki sztab generalny widział w drużynach, w razie konfliktu zbrojnego, formacje regularne pełniące służbę wywiadowczą i komunikacyjną, a więc pomocniczą. Ale i były takie koncepcje, by przy pomocy tych oddziałów wywołać powstanie w Królestwie na początku ewentualnej wojny lub nawet niezależnie od niej, jako najfatalniejsze wystąpienie samodzielne. I nad taki wystąpieniem, a więc bezpośrednią akcją powstańczą, jako prowokacją, pracować miał Redl. Balicki zauważa rozbieżność koncepcji sztabu generalnego i biura ewidencyjnego.

Redl pracował więc nad szerzeniem się ,azewszczyzny” powstańczej w Galicji. Publicysta zawierza informacjom prasowym, że Redl był Żydem galicyjskim, który dla kariery zmienił swoje nazwisko Redlich na jego derywat, brzmiący bardziej niemiecko i mieszczańsko. I buduje na tym antysemicką tezę, że nie powinno dziwić, iż na czele owej azewszczyzny stanął Żyd, gdyż dzieje rewolucji rosyjskiej udowodniły, że prowokacja polityczna jest ,jednym z ponurych przejawów duszy semickiej”. Redlich stawiany jest przeto w rzędzie takich prowokatorów, jak Azef czy Bakaj. Balicki sugeruje, że ruch niepodległościowy w ogóle inspirują i podtrzymują Żydzi; padają nazwiska, między innymi Wilhelma Feldmana, a lwowski „Wiek Nowy”, określany zostaje mianem dziennika żydowskiego i „niemal organu” Komisji Tymczasowej. W tym kontekście przeprowadzony zostaje gwałtowny atak na ,stronnictwa skonfederowane", i postawione retoryczne pytanie, czy przeprowadziły one śledztwo odnośnie do możliwości ulegania prowokacji w swoich działaniach. Ale, jak stwierdza publicysta, Komisja Tymczasowa nie poczuwa się nawet do dania odpowiedzi na te i inne pytania, może dlatego że jest „koterią od narodu oderwaną”.

Artykuły zamieszczane w „Gazecie Porannej 2 Grosze” przedrukowywano i aprobatywnie komentowano w dziennikach i periodykach endeckich, czerpiąc zeń polityczne wątki służące kompromitacji ruchu niepodległościowego. Ale spectrum prasy warszawskiej było znacznie szersze, i nie wszystkie tytuły podzielały racje „dwugroszówki”. Jako przykład służyć może zorientowana antyendecko, antyklerykalnie $^{43}$ i występująca przeciw trójlojalizmowi „Prawda”. W tygodniku skomentowano aferę Redla jako „olbrzymi skandal, który podważa w najintymniejszych głębiach fundamenty moralne i militarne potęgi habsburskiej" ${ }^{4}$. Nie przywoływano jednak związanych z tą sprawą szczegółów, i zapewne spotkałoby ją na łamach tego pisma przemilczenie, gdyby nie artykuły w „Gazecie Porannej 2 Grosze”, które sprowokowały jego redakcję do ostrej reakcji. W rubryce Echa prawdy ${ }^{45}$ zaatakowano rewelacje „dwugroszówki” jako brednie i „skandaliczne oszczerstwa”, o tyle niebezpieczne,

43 Charakterystyczny tytuł artykułu wstępnego, odnoszącego się do listu pasterskiego, o którym kilkakroć była mowa: Biskupi przeciw narodowi. „Prawda” 1913, nr 22 (31 maja), s. 1-4.

44 „Prawda” 1913, nr 23 (7 czerwca), s. 5 (w rubryce Przegladu politycznego).

45 „Prawda” 1913, nr 25 (21 czerwca), s. 3. 
że dotykające ludzi cieszących się zaufaniem publicznym: Tetmajera, Śliwińskiego i Daszyńskiego. Endecki dziennik wymyślił, że Redl musiał się kontaktować z posłami Koła polskiego, ale tylko z tymi, którzy są nie po jego linii politycznej. Skorzystał z pogłoski, że Azef znajdował się w Wiedniu, więc kontakt z nim musieli mieć znienawidzeni przez „,dwugroszówkę” posłowie. Redl, ironizuje „Prawda”, „organizował po prostu komisję tymczasową i związki strzeleckie, Redl prowadził politykę obozu, w którego skład wchodzą najpopularniejsze w Galicji stronnictwa”. Nie wśród austrofilów, szydzi dalej, szukać trzeba wspólników zdemaskowanego szpiega, bo nie dla Austrii on pracował. „Dwugroszówka”, czytamy dalej, nie zasługuje, by z nią polemizować, tym bardziej, że jej insynuacje spotkały się z reakcją oburzenia i obrzydzenia wśród części opinii publicznej.

„Prawda” zareagowała również na artykuł Balickiego. Mowa tu o polemicznym komentarzu Orientacja rumuńska, w którym wzmiankowany artykuł oceniony został jako pełen „,faktycznych fałszów i insynuacji” ${ }^{\prime 4}$. Wywołał on już protest posła Daszyńskiego zamieszczony w pismach krakowskich, podobnie jak odpowiedź Józefa Piłsudskiego. Tytuł komentarza sugerować ma, że treści artykułu Balickiego i jego endeckich egzegetów reprezentują „orientację rumuńską”, co było wówczas obiegowym dyskwalifikującym epitetem, bowiem część opinii publicznej uważała, że Rumunia cynicznie wykorzystała wznowioną wojnę na Bałkanach, i bez żadnej z jej strony ofiary uzyskała największe łupy.

Ukazujący się w Warszawie „Tygodnik Polski”, podważający racje lojalizmu jako poniżające i jałowe, nie znajdujące zrozumienia w Rosji, również odniósł się do sposobu komentowania afery Redla przez „Gazetę Poranną 2 Grosze”. W rubryce $U w a g i^{47}$, podkreślono, że sam fakt jest przykry i kompromitujący nie tylko dla Austrii, ale i również dla „ościennego mocarstwa” (to określenie wzięto w cudzysłów), bo i w nim często zdarza się uprawianie procederu szpiegowskiego. Naturalnie, to są sprawy skandaliczne, na których podłożu tworzyć można „najbardziej fantastyczne sylogizmy". Jednakże, wywodzi redaktor, nawet w wytworach fikcji winno się „zachować miarę i pewne przynajmniej pozory poczytalności”. Tymczasem, ironizuje, przejęta „do żywego" szpiegowskim skandalem "Gazeta Poranna 2 Grosze”, chciałaby się dowiedzieć, z kim Redl utrzymywał stosunki podczas swojego pobytu w Warszawie. Widocznie - prześmiewczo odpowiada - przeoczyła drukowaną wszędzie informację, że spotykał się on z pewną szansonistką z kabaretu Aquarium.

Krakowska „Krytyka” była czołowym organem propagowania idei niepodległościowych i popierania „polityki wojennej” Austro-Wegier. Miesięcznik redagowany był przez Wilhelma Feldmana, swoje artykuły publikował w nim między innymi Władysław Studnicki. Głoszono w nim hasła przeobrażenia Austrii w „,federację narodów" bądź w państwo autro-słowiańsko-węgierskie, mogące stać się nie tylko antytezą dla Rosji, ale i dla Niemiec. W Galicji widziano Piemont Polski, uznawano po-

46 „Prawda” 1913, nr 32 (9 sierpnia), s. 4. Autorką komentarza prawdopodobnie jest I[za] M[oszczeńska].

47 „Tygodnik Polski” 1913, nr 23 (5 czerwca), s. 365. Redaktor podpisany kryptonimem: (d.). 
lityczne aspiracje Rusinów. Antyczechizm łączono z madziarofilstwem, a to ostatnie nastawienie w dobie wojen bałkańskich mocno się depopularyzowało, gdyż nawet zdeklarowani wyznawcy idei trializmu, za największą przeszkodę do jej urzeczywistnienia uważali nieprzejednane stanowisko Wegrów, obstających przy zachowaniu ustroju dualistycznego, który zapewniał im hegemonistyczną pozycję wobec Słowian. „Krytyka” czy lwowski dwutygodnik „Rzeczpospolita”"48 wyróżniały się właśnie takim punktem widzenia.

„Krytyka” uważnie śledziła sprawy związane z Komisją Tymczasową i drużynami strzeleckimi w rubryce $Z$ ruchu niepodległościowego. Zwalczała prasę warszawską jako przeważnie moskalofilska, przeciwstawiając ,polskiemu pogotowiu wojennemu" w Galicji pasywizm i postawę godzenia się z losem Królestwa. W szczególności piętnowała panslawizm, także w wydaniu czeskim (grupa Klofácza). Wydawać by się mogło, że redakcja niezwłocznie zareaguje na aferę Redla, by móc niejako z góry dać odpowiedź na pytania, które cisnęły się na usta opinii publicznej, niekoniecznie w jej części endeckiej. Można było narzucić swoją interpretację, jak uczynił to „Ilustrowany Kurier Codzienny”, w każdym razie należało z powodów politycznych sprawę zneutralizować.

Tymczasem „Krytyka” odpowiedziała nie jakimś specjalnej wagi artykułem wstępnym, lecz polemiką z „Gazetą Poranną 2 Grosze”, umieszczonej we wzmiankowanej rubryce ${ }^{49}$. Redaktor pisze:

Znając poziom moralny i metody walki naszych, polskich, wrogów ruchu niepodległościowego, ani na chwilę nie można było wątpić, że zechcą przykładnie wyzyskać Redla dla celów Targowicy.

Nie podaje jednak literalnie faktów czy przypuszczeń, które stwarzały pożywkę dla przeciwnika politycznego, umożliwiającą rozpętanie „kampanii oszczerstw” przeciwko ruchowi niepodległościowemu. Trzeba by stwierdzić, i wydać jakieś stanowcze dementi, zaprzeczające możliwości infiltracji Komisji Tymczasowej i drużyn strzeleckich przez Redla. Tymczasem poprzestano na ataku na „osławioną” „Gazetę Poranną 2 Grosze”, a zwłaszcza na tekst Splatane sieci, zamieszczony w numerze 152 tego dziennika, jakoby zainspirowany przez Dmowskiego. Mowa jest też w tej polemice o przedrukach z ,dwugroszówki” w całej prasie ugodowej (padają tytuły dzienników warszawskich, lwowskich i poznańskich). Porównanie Redla do Azefa zostaje sprowadzone do absurdu, wytyka się też zupełną bezpodstawność insynuacji skierowanych pod adresem posłów Śliwińskiego, Tetmajera i Daszyńskiego. Podkreśla się też powagę Komisji Tymczasowej, której znaczenie rośnie w kręgach Polonii amerykańskiej, i dostrzega zainteresowanie Francji ruchem niepodległościowym (niekoniecznie przyjazne, ale liczące się jako fakt), co ma być pośrednim skutkiem wypadków na Bałkanach. Polemika odbywa się zatem na gruncie zarzutów poczynionych

48 Por. artykuł Węry i ich sprawy w prasie polskiej, „Rzeczpospolita” 1913, nr 101 (21 czerwca). Autor podpisany kryptonimem C. R.

49 „Krytyka” 1913, T. XXXIX (Dział polityczno-społeczny), s. 44-46. Inicjał redaktora: (l). 
przez przeciwnika politycznego, co stronę broniącą się stawia w trudnej sytuacji. Z drugiej strony widać jednak, że można było znajdować argumenty podnoszące racje wyznawane przez „Krytykę”.

Najpoważniejszą odpowiedzią na Dezorientację austriackq okazał się artykuł Józefa Piłsudskiego Orientacja pana Balickiego, który ukazał się w numerze krakowskiego „Naprzodu” z 30 lipca 1913 roku (s. 1-2). Była to odpowiedź dość spóźniona, ale za to zdecydowanie uderzająca w tezy i argumentację przeciwnika. Wycieczka czołowego ideologa endecji spotkała się z ripostą lidera ruchu strzeleckiego, który tłumaczy specjalne zainteresowanie artykułem Balickiego tym, iż ten, korzystając z insynuacji „dwugroszowych pismaków”, „usystematyzował kalumnie”, podpisał je własnym nazwiskiem i nadał znaczenie wypowiedzi politycznej. Posłużył się zatem ów - jak się domyślamy - liczący się adwersarz polityczny - tam marnym tworzywem, jakim są „różne brednie tandetnie obsługiwanej prasy polskiej”. Piłsudski powtarza tę myśl o miałkości prasy polskiej, skłonnej do szerzenia „,potwornych baśni”, jak ta o aferze Redla, bez zadania sobie najmniejszego trudu w sprawdzaniu wiarygodności źródeł. A przecież niekiedy można to uczynić bardzo łatwo, sięgając do informacji jawnych, dotyczących na przykład „schematyzmu wojskowego" armii austro-węgierskiej”, ,źródła dostępnego dla wszystkich”. Wyczytać z niego można, że szefem biura ewidencyjnego był pułkownik Ritter von Ostrymiecz Urbański, a nie Redl, nazwisko - ironizuje Piłsudski - „o ile mi się zdaje, nie żydowskiego pochodzenia".

Istotnie, stanowisko szefa sztabu generalnego (korpusu) mylono ze stanowiskiem szefa cesarsko-królewskiego sztabu generalnego (armii). Piłsudski podaje informację, że służba Redla jako oficera (o specjalnie nie wyszczególnionej funkcji) w sztabie generalnym armii kończy się na początku 1911 roku, następnie jako podpułkownik służy on w 99. pułku piechoty i jako pułkownik zostaje awansowany na szefa sztabu VIII korpusu. Według Piłsudskiego wiązanie Redla z ruchem strzeleckim jest nonsensem, gdyż pierwszy związek strzelecki w Galicji powstał w końcu 1910 roku, co się prawie zbiegło z zakończeniem służby Redla w sztabie generalnym w Wiedniu. Rozwój tego ruchu - zaznacza - w ogóle „mało popierany przez wojskowość austriacką”, rozwinął się dopiero w roku 1912, „kryzysowym” z powodu wojny na Bałkanach. Redl w żaden, więc, sposób nie mógł mieć ani wpływu ani nawet kontaktów z niepodległościowcami, a sama myśl o możliwości kierowania przez szefa sztabu korpusu praskiego „ruchem irredentystycznym w Polsce” jest absolutnym nonsensem. Podobnie jak domniemanie, że Redl mógł odgrywać jakąkolwiek rolę i w ten sposób pozyskać wiedzę o strategicznych planach wojny, nie miał on nawet dostępu do informacji dotyczących innych, poza własnym, korpusów.

Piłsudski ironizuje, iż ubliża to nawet Rosji, iż ta w obliczu wojny z potęgą militarną Austro-Węgier i Niemiec, miałaby delegować najwyższej klasy swojego szpie- 
ga „do tak względnie nikłych rzeczy, jak prowokatorskie organizowanie Związków i Drużyn strzeleckich i komunikowania się z posłami polskimi w Wiedniu"son.

Zabawa Balickiego w Sherlocka Holmesa byłaby - powiada Piłsudski - czymś śmiesznym i naiwnym, gdyby nie to, że okazała się ,potwornie wstrętną”. Dyzgust estetyczny, wyrażany w retoryce świętego oburzenia, idzie w parze z wycieczką ideologiczną skierowana przeciwko Narodowej Demokracji i podzielającym jej racje tytułom prasowym. Endecja ma reprezentować „prąd moskalofilstwa”, nie przyjmujący do wiadomości, podobnie jak rząd rosyjski, że poza nim może istnieć jakikolwiek „ośrodek kierowniczy” polityki polskiej. Piłsudski szydzi, że dla wyjaśnienia "tak potwornego zjawiska w życiu ujarzmionego narodu”, jakim jest dążenie do walki o niepodległość, poszukuje się insynuacyjnie „brudnych i wstrętnych źródeł”. Balicki, który „haniebnie i oszczerczo brudne błoto rzuca” zaliczony zostaje w poczet ,gadzinowców moskiewskich”, ciskających anatemy na hasła rewolucyjne, niegdyś przez nich wyznawane. To, naturalnie, przytyk do wczesnej biografii politycznej Balickiego.

Artykuł Piłsudskiego niósł z sobą niemały zasób argumentów zwalczających endecką tezę o kierowniczej roli Redla w organizacji ruchu strzeleckiego i o jego kontaktach z politykami niepodległościowymi. W dodatku argumenty te, wyłożone z pasją i niejako ze wstrętem zbijające ,potworne” i „ohydne” treści wywodów Balickiego, miały swoje pierwszorzędne znaczenie polityczne. $\mathrm{W}$ ten sposób, bowiem, wyrażony został punkt widzenia wybitnego niepodległościowca na sposób i styl wykorzystania afery Redla przez endeków. Balickiemu odpowiedział Piłsudski, co sugerowało wagę tej polemiki, jako konfrontacji ideologicznej. Ale odpowiedź była spóźniona, i nadeszła ona w momencie, gdy prasa warszawska przestała zajmować się aferą szpiegowską. Komentarze „dwugroszówki” zdołały już obiec całą prasę polską, zwłaszcza tę, która wyznawała racje Narodowej Demokracji. A były to dziesiątki tytułów dzienników i tygodników ukazujących się na ziemiach polskich pozostających pod władzą trzech cesarzy.

Afera Redla spotkała się z ogromnym zainteresowaniem prasy polskiej, stając się jednym z ważniejszych czynników polaryzacji polskiej opinii publicznej na dwie główne orientacje polityczne, które ostatecznie skrystalizuje wybuch wojny europejskiej. Zdemaskowanie agenta rosyjskiego odsłaniało słabość c. k. armii i nadwerężało prestiż monarchii Habsburgów na arenie międzynarodowej. Ustawiało galicyjski aktywizm pod tym względem w pozycji defensywnej, a że afera wydarzyła się w momencie osłabnięcia napięcia pomiędzy mocarstwami, oddalając nadzieje niepodległościowców na wybuch wielkiej wojny, pomniejszyła ona powagę ,pogotowia wojennego".

Przedstawiliśmy szereg wątków politycznych związanych z „wprost niebywałą sprawą szpiegowską", respektując kontekst politycznych wydarzeń w AustroWęgrzech i w Galicji, na które wpływ miała wojna na Bałkanach. Nie rozgrywała się

50 J. Piłsudski, Pisma zbiorowe. Wydanie prac dotychczas drukiem ogłoszonych, Redakcja, wstęp i przypisy Wacław Lipiński, tom III, Warszawa 1937, s. 186. 
ona, bowiem, w jakiejś abstrakcyjnej przestrzeni, a jej psychopolityczna irradiacja wywoływała skutki w świadomości narodów c. k. Monarchii, wytwarzając coraz bardziej skonfliktowane z sobą dwa typy postaw: sprzymierzeńca (zwolennika trializmu) i rozłamowca (pragnącego rozpadu monarchii Franciszka Józefa). Oczywiście, to podział nadzwyczaj ogólny, gdyż na przykład polski niepodległościowiec jest sprzymierzeńcem Austro-Węgier, czeski raczej odwrotnie (bo nadzieje na suwerenność wiąże z Rosją), a chorwacki czy bośniacki spogląda w stronę Serbii i pragnie widzieć swój kraj nie jako odrębne państwo, ale w ramach federacji jugosłowiańskiej.

W pryzmacie afery Redla rozszczepiają się pasma różnorakich spraw politycznych, w tym konfliktów narodowościowych, które zdawały się rozsadzać c. k. Monarchię. Konflikty te odsłaniały się w dyskursie prasowym na różnych płaszczyznach, na przykład sprawy narodowości Redla, morale korpusu oficerskiego armii austrowęgierskiej czy Izby poselskiej i sejmów krajowych, które stawały się coraz bardziej zantagonizowanym forum reprezentowania interesów narodowych. Nie oznacza to, iż ten dysfunkcyjny parlamentaryzm nadwerężał ustrój państwa. W końcu to była monarchia, która może - i to byłoby paradoksem - mogła całkiem dobrze funkcjonować właśnie dzięki zasadzie „divide et impera”, której stosowanie przerzucono także na fora parlamentarne. A więc względna równowaga poprzez lokalizowanie konfliktów w politycznej przestrzeni poselskich walki frakcji narodowościowych. Ale i słabość wskutek przesycenia narodowością tkanki politycznej mocarstwa. Sądzić wypada, że afera Redla daje więcej do myślenia, niżby to wynikało tylko z powodu jej sensacyjnego charakteru. I tak to odebrać można, interpretując treści doniesień i komentarzy prasowych sprzed stulecia.

\title{
COLONEL REDL. POLITICAL MOTIFS OF THE AFFAIR IN POLISH PRESS RELEASES.
}

\begin{abstract}
Summary
The most famous spy scandal before the outbreak of the First World War, took place during the time of intensified diplomatic actions taken to stop the Balkan War. At night on May 24 $4^{\text {th }} 1913$, Colonel Alfred Redl, the chief of staff for the VIII. Corps stationed in Prague - having been exposed by counterintelligence-committed suicide in Klomser Hotel in Vienna. His death was directly connected to the fact that the special commission that consisted of high ranking officers was established in the extraordinary mode. The case of Russian spy was known only to an exclusive group of 'initiates'. Nevertheless, it was almost immediately leaked to the press and evoked scandal that stirred up public opinion in Austria-Hungary.

The motifs of the scandal - described in Polish press releases of that time: in Cracow, Lvov and Warsaw - have been analyzed in the article. They were significant in the context of political struggle, led mainly between two antagonistic forces: the Austrophiles and the Russophiles. Seemingly distant from
\end{abstract}


Polish matters, the spy affair turned out to be an important factor that 'catalyzed' political attitudes of the Poles. The aspect of Redl's nationality became a significant element of the polemics. And the scandal undermined Austro-Hungarian morale, especially the morale of Slavic nations subject to the Empire; the more so as, at exactly the same time, a political corruption affair which Hungarian Prime Minister was involved in, happened in Budapest. The events that happened in Galicia in May and June 1913 - as connected with political and economical turning point that autonomous country reached, which was caused by Austro-Hungarian preparations for Balkan War - have been examined here as the background context.

In this article, basing on a wide range of press sources, the author classifies and describes some key political motifs of the Redl affair: especially the change of ideas about the Balkan War - in accordance to common opinions expressed in Polish press - now bringing the fatal threat to Austro-Hungary. (Russia came into possession of mobilization plans). The other topics are: the decline of Austro-Hungarian prestige on the international arena, the criticism of the code applying to officer corps, assigning Redl the Jewish origin by the anti-Semitic press, attacks on the ones that supported Austro-Hungarian orientations, including those who organized a kind of "substitute" for Polish military forces under the auspices of the monarchy, and finally - the spy psychosis. 